Original article

\title{
Turizm Sektöründe Çalışan Kadınların İş-Aile Çatışması ve Tükenmişlik Düzeylerinin, Örgütsel Bağlılıklarına Olan Etkisinin İncelenmesi Üzerine Bir Araştırma
}

\section{A Study on The Effects of Work-Family Conflict and Burnout Levels of Women Working in the Tourism Sector on Their Organizational Commitment}

\author{
Mehmet Sedat İpar (10 * \\ Department of Gastronomy and Culinary Arts, Faculty of Tourism, Eskişehir Osmangazi University, Eskişehir, Turkey
}

\begin{abstract}
Özet
Hizmet sektörünün önemli bir dalı olan turizm sektöründe alanında istihdam edilen kadın çalışanlara yönelik son yıllarda gerçekleştirilen akademik çalışmalarda, kadınların özellikle toplumsal rolleri ile yaptıkları iş arasındaki etkileşimler incelenmektedir. Kadın istihdamının turizmin daha önce erkek egemen olan bazı alanlarında da son yıllarda artış göstermesi ile birlikte küresel anlamda kadınların hizmet sektöründeki istihdam oranı ve başarısı da bu araştırmalara temel oluşturmaktadır. Toplum içerisinde gerek mesleki anlamda aldıkları eğitim doğrultusunda çalışmak gerekse bu kapsamda kariyer yapma istekliliği, kadın çalışanların başarııını arttıran önemli etkilerdendir. Ancak bu durumla birlikte kadınların üretime veya hizmete yönelik sektörlerde üstlendikleri görevleri, aile hayatlarında çeşitli sorunları beraberinde getirmektedir. Bir taraftan sorunlarla mücadele eden kadın çalışanlar diğer taraftan ise işleri ile ilgili yükümlülükleri yerine getirmeye çalışırken tükenmişlik belirtileri göstermekte ve çalıştıkları örgüte bağlıık düzeylerinde farkıııklar görülmektedir.

Gerçekleştirilen araştırmada, farklı turizm işletmelerinde ve farklı departmanlarda hizmet veren kadın çalışanların iş-aile çatışması ve tükenmişlik düzeylerinin, örgütsel bağlııklarına olan etkisi incelenmeye çalışılmıştır. Bu kapsamda Türkiye’nin turizm hareketliliğinin en yoğun yaşandığı Akdeniz Bölgesi’nde Antalya'da bulunan konaklama işletmelerinin farklı departmanlarında görev yapan 504 kadın personelden anket tekniği ile veriler elde edilmiştir. Gerçekleştirilen istatistiki analiz sonrasında kadın çalışanların karşılaştıkları iş-aile çatışması ve tükenmişlik düzeylerinin, örgütsel bağlılılarını pozitif yönde etkilediği tespit edilmiştir.
\end{abstract}

Anahtar Kelimeler: Turizm ve Kadın, Kadın Çalışanlar, İs-Aile Çatışması, Tükenmişlik, Örgütsel Bağlılık.

\begin{abstract}
In recent years, academic studies on female employees employed in the tourism sector, which is an important branch of the service sector, examine the interactions between women's social roles and their jobs. Along with the increase in female employment in some previously male-dominated areas of tourism, the employment rate and success of women in the global service sector form the basis of these studies. The willingness to work in the society in line with the professional education they have received and to
\end{abstract}

\footnotetext{
* Corresponding author:

Mehmet Sedat Ipar, Department of Gastronomy and Culinary Arts, Faculty of Tourism, Eskişehir Osmangazi University, Eskişehir, Turkey. Email:m.sedatipar@gmail.com
} 
make a career in this context are important effects that increase the success of female employees. However, with this situation, the duties that women undertake in production or service sectors bring along various problems in their family life. On the one hand, female employees who struggle with problems, on the other hand, show signs of burnout while trying to fulfill their jobrelated obligations, and there are differences in the level of commitment to the organization they work for.

In the research carried out, the effect of work-family conflict and burnout levels of female employees serving in different tourism businesses and different departments on their organizational commitment was tried to be examined. In this context, data were obtained by survey technique from 504 female personnel working in different departments of accommodation establishments in Antalya, where Turkey's tourism activity is the most intense. After the statistical analysis, it was determined that the levels of workfamily conflict and burnout faced by female employees positively affect their organizational commitment.

Keywords: Tourism and Women, Woman Employees, Work-Family Conflict, Burnout, Organizational Commitment.

\section{GİRiş}

İçerisinde bulunduğumuz zaman diliminde dünya nüfusunun giderek artması sonucu toplumu oluşturan bireyler, insanlığın en temel ihtiyaçları olan beslenme, barınma, eğitim, sağlık imkânlarına ulaşmada zorluklar yaşamaktadır. Bu zorlukların getirdiği sosyal, kültürel, ekonomik ve psikolojik etkilerin yanı sıra bireylerin hayatlarını devam ettirebilmeleri için çalıştıkları kurumlarda, işleri veya meslekleri ile ilgili üstlendikleri sorumluluklar da onlarda fiziki veya duygusal birtakım etkiler yaratmaktadır. Günümüzde mal veya hizmet üreten tüm sektörlerdeki çalışanlar genel anlamda yoğun iş yükü, çalışan performansına dayalı bir takım ödül ve ceza sistemleri, müşteri memnuniyetini üst seviyede tutma, uzun çalışma saatleri gibi etkenlerin yanı sıra iş güvencesizliği, eğitim aldığı alanlarda iş imkânı olmadığından mecburen bulunduğu işletmede çalışmak zorunda kalmak, yapılan işin karşılı̆̆ olan ücreti alamamak, iş tanımı dışında kalan görevleri yerine getirmek, işyerinde üst yönetimler tarafından psikolojik şiddete maruz kalmak gibi birbirinden farklı olumsuzluklarla karşılaşmaktadır. Ek olarak değişen ve gelişen teknolojik yapı da iş dünyasında en alt kademeden en tepe noktasına kadar bireylerin kendilerini sürekli geliştirmesini zorunlu kılmaktadır.

Tüm bu olumsuz koşulların yanında kadınlar, kendilerine yüklenen toplumsal görev ve sorumluluklarla başetmeye çalışmaktadır. Genel anlamda toplumlarda erkeklerin çalışma ve ailesine bakma yükümlülüğü kapsamında üstüne atfedilen toplumsal roller ile birlikte ataerkil toplum yapıları, kadınların başta endüstriyel üretimin olmak üzere hizmet sektöründe de istihdam edilebilmesi aşamasında birtakım engeller oluşturmaktadır. Her ne kadar 2000'li yıllardan sonra toplum içerisinde kadınların eğitim seviyesinin giderek yükselmesi, kariyer sahibi olmaları ve toplum için önem arz eden çeşitli mesleklerde öncü olmaları gibi örneklere sıklıkla rastlanıyor olsa da, genel anlamda toplum yapısı içerisinde kadına yüklenen aile içi toplumsal rollerde değişiklik görülmemektedir. Sosyolojik açıdan 
değerlendirildiğinde toplum içerisindeki çeşitli eşitsizliklere en fazla maruz kalan kadınlar, eğitim imkânlarında, işe alımlarda, terfilerde, iş bölümünde, ücretlendirmede adil olmayan uygulamalarla karşılaşmaktadır. Ayrıca, hamilelik ve bebeklik ile erken çocukluk dönemlerinde kadınların artan iş yüklerinin yanı sıra karşılaştıkları psikolojik ve cinsel taciz gibi kabul edilemez davranışlar, kadınların iş yaşamlarında fiziksel ve ruhsal çöküntü yaşamalarına, aileleri ve işleri arasında kalmalarına ve tükenmişlik sendromu ile karşı karşıya kalmalarına neden olmaktadır.

Hizmet sektörünün önemli bir dalı olan turizm sektöründe; konaklama işletmeleri, yiyecek içecek işletmeleri, seyahat işletmeleri ve rekreasyon işletmeleri başta olmak üzere sektörel anlamda kadın istihdamı, kadın çalışanların sektördeki yeri ve sorunları üzerine gerçekleştirilen çalışmaların son yıllarda giderek arttığı görülmektedir. Ayrıca Türkiye'de pek çok üniversitede oluşturulan kadın araştırma merkezlerinde kadınların toplumsal, siyasal, ekonomik ve sektörel haklarında bilinç oluşturmak, aile içi iletişim, kişisel gelişimleri açısından eğitimler vermek üzere araştırmalar yapılmaktadır. Turizm alanyazınında kadın çalışanların iş-aile çatışması ve tükenmişlik düzeylerine yönelik çalışmalara yer verilmeye başlandığı görülmekle birlikte bu iki boyutun örgütsel bağlılık üzerindeki etkisini inceleyen araştırmalar oldukça sınırlıdır. Çalışmada, farklı turizm işletmelerinde ve farklı departmanlarda hizmet veren kadın çalışanların iş-aile çatışması ve tükenmişlik düzeylerinin, örgütsel bağl1lıklarına olan etkisi incelenmesi amaçlanmıştır. Bu kapsamla çalışmada öncelikle iş-aile çatışması, tükenmişlik kavramı ve örgütsel bağlılık ile ilgili alanyazına kısaca değinilmiş ve kadınların turizm sektörü içerisindeki öneminden bahsedilmişir. Ardından araştırmaya ilişkin yöntem, evren, örneklem ve veri toplama yöntemi ile bulgulara yer verilmiştir. Çalışma, konu ile ilgili değerlendirmeler ve araştırmacılara önerilerle sonuçlandırılmıştır.

\section{KAVRAMSAL ÇERÇEVE}

\section{İş-Aile Çatışması}

Çatışma kavramı, kişi veya toplulukların yaşadığı uyumsuzluk süreci olarak tanımlanır (Çarıkçı ve Çelikkol, 2009: 154). Kişinin kendi içerisinde yaşamış olduğu tutarsızlık ya da uyumsuzluk süreci olarak da değerlendirilebilen çatışma kavramı (Genç, 2004; Çarıkçı ve Çelikkol, 2009), bireysel ve örgütsel çerçevede incelenir. Bireysel çatışmada kişi, karar verme sürecinde yaşamış olduğu zorlukların yanı sıra verdiği karardan sonra da pişman olabilmektedir. Örgütsel çatışmada ise, bir işletmede çalışan insanların, yönetim veya diğer işgörenler ile eşgüdümlü çalışamaması, iş ile ilgili konulara veya toplum yaşamına uyumsuzluk durumu oluşmaktadır (Çarıkçı ve Çelikkol, 2009: 154).

Çalışanların aynı anda, çalışan anne-baba ve eş gibi birden fazla role sahip olması ve bu rollerin birbirleri ile çatışmasından ortaya çıkan iş-aile çatışması (Turunç ve Çelik, 2010: 212), iki farklı açıdan ele alınabilir (Wayne vd.,2004: 108; Seçilmiş ve Kılıç,2017: 67). Bunlardan ilki, bireylerin mesleklerinde ve iş ile ilgili yükümlülükleri yerine getirmede psikolojik ve fiziki olarak yıpranmaları 
gereği aile içinde üstlenmesi ve yerine getirmesi gereken sorumluluklardan kaçma veya tam olarak yerine getirememeleri ile ilgilidir. İkincisi olarak ise, bireylerin aile içerisinde yaşadığ çeşitli olumsuzlukların ruh halini etkilemesi, mental açıdan yoğunluk oluşturması ve bu nedenle de iş ile ilgili yükümlülüklerini yerine getirmede zorlanmasıdır. Her iki durumda da kişi, iş-aile ilişkisi bakımından olumsuz etkilenmektedir. Diğer taraftan toplum içerisinde bulunan bireylere, geleneksel ve kültürel bakımdan yüklenen toplumsal roller de iş-aile çatışmasını tetikleyici bir durum ortaya çıkarmaktadır. Greenhaus ve Beutell (1985:77) çalışmalarında iş aile çatışmasının ortaya çıkmasında üç ana sebebin olduğunu belirtmişlerdir. Bunlar;

- Zamana Dayalı Çatışma (Time-Based Conflict): Zamana dayalı çatışma kişilerin yerine getirmesi gereken sorumluluklara yetişememesi sonucu ortaya çıkmaktadır.

- Gerilime Dayalı Çatışma (Strain-Based Conflict): Gerilime dayalı çatışma, kişilerin iş ya da aile içinde karşı karşıya geldikleri stresten dolayı ortaya çıkan çatışma türü olarak tanımlanabilir.

- Davranışlara Dayalı Çatışma (Behavior-Based Conflict): Davranışlara dayalı çatışma, ise kişilerin birbirlerine olan uyumsuz davranışları dolayısıyla gelişmektedir.

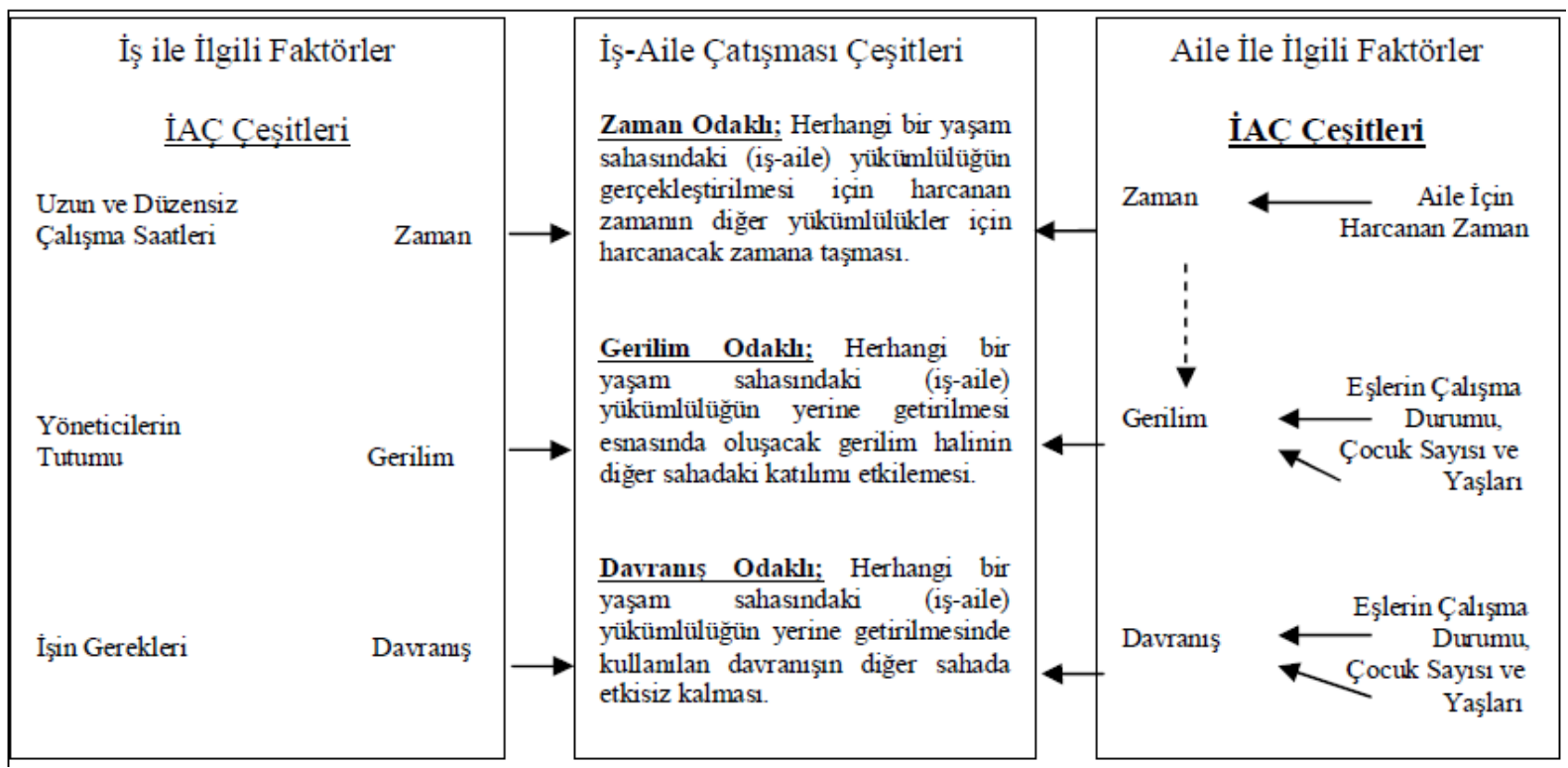

Şekil 1: İş-aile çatışması Türleri ve Nedenlerinin Eşleştirilmesi

Kaynak: Diker, 2010: 49.

Şekil 1'de görüldüğü üzere uzun ve düzensiz çalışma saatleri, fazla mesai, özerklik durumu, örgütün büyüklüğü, düşük ücret, üst yönetimin olumsuz tavrı, iş ilişkileri, kişinin işte bulunma süresinin uzunluğu, terfi, aile ilişkileri, aile beklentileri, sağlık durumu, çocuk sayısı, yaş, gelir, çalışan performansı gibi çeşitli iş ve kişisel özellikler iş-aile yaşam çatışmasının en önemli nedenleri arasındadır (Turunç ve Erkuş, 2010: 418). Anne, baba, eş, evlât olmak gibi sorumlulukların yanı sıra işleri ile ilgili yoğun tempoda çalışan bireyler belirli bir zaman dilimi sonrası çeşitli fiziki ve mental yıkımlara 
uğrayabilir. Toplumu oluşturan bireylerin geneli olduğu gibi özellikle de kadınlar hem toplum tarafından kendine yüklenen rolleri yerine getirmeye çabalarken hem de işleri ile ilgili sorumlulukları gerçekleştirmeye çalışmaktadır (Özdevecioğlu ve Çakmak Doruk, 2009: 71). Bu iki etken arasında kalan kadınların bir süre sonra yaşam kaliteleri de azalmaktadır (Yüksel, 2005: 303). Üstelik bu iki alandaki sorumluluklarını bir de aynı anda yerine getirmeye çalışmak oldukça yorucu ve yıpratıcı bir durumdur. Yoğun iş temposu, çalışma süresinin uzunluğu, iş ile ilgili haklardan yararlanma aşamasındaki sıkıntılar ve fazla mesailerin yanı sıra kadın olmanın getirmiş olduğu çeşitli dezavantajlar (Turgut, 2011: 159) bir süre sonra kişisel stres, kaygı bozukluğu, kendini yetersiz hissetme gibi duygusal çöküntülerle birlikte tükenmişlik oluşturabilir (Çarıkçı ve Çelikkol, 2009: 156).

\section{Tükenmișlik Kavramı}

Çalışma hayatı içerisinde bireyler işleri ile ilgili uğraşlarının yanı sıra bireysel yaşamlarında yerine getirmesi gereken sorumlulukların üstesinden gelmeye çabalarlar. Bazıları için bu ikisi arasındaki çabalar kısa ve orta vadede çözümlenirken bazı bireyler uzun denilebilecek bir zaman diliminde işleri, aileleri ve çevrelerindeki olumsuzluklarla baş etme durumunda kalır. Bu uzayan sürecin meydana getirdiği birtakım negatif duygusal ve fiziksel etkiler bireylerde tükenmişlik sendromunun ortaya çıkmasını beraberinde getirir (Oğuzberk ve Aydın, 2009:168). İş yükü, işe veya ailesine aidiyet duygusu, çalışma baskısı, kişilerarası uyuşmazlık, stres, başarısızlık hissi, doyumsuzluk, rol çatışması, karamsarlık, maddi ve sosyal güvence endişesi, toplumsal değerler, cinsiyet ve cinsiyetleri nedeniyle maruz kaldıkları bir takım tutumlar sonucu mesleğe karşı ilginin azalması ve umutsuzluk gibi pek çok neden bireyleri tükenmişlik içerisine sürüklemektedir.

Alanyazında ilk defa 1961 yılında Greene tarafından kullanılan tükenmişlik kavramını, 1974'de Freudenberger'in; "Çalışma hayatına sahip olan tüm bireylerin yaşayabileceği bir durum olarak nitelendirmesinin yanı sıra çalışanlar için bir tehlike olarak görmesi ve yoğun talepler karşısında yaşanılan stresin sebebiyet verdiği yıpranma" olarak tanımlaması sonucu bu kavram ruh sağlığı alanyazınına girmiştir. 1981 yılında ise Maslach ve Jacson tarafından Maslach Tükenmişlik Envanteri oluşturulmuştur. Ayrıca tükenmişlik kavramı bireylerin iş hayatındaki yoğun duyguları sebebiyle ortaya çıkabilen bitkinlik, yorgunluk, umutsuzluk gibi duygulara yol açan bir etken olarak tanımlanmıştır. Ek olarak tükenmişliğin kişilerde duyarsızlaşma, duygusuzlaşma ve kişisel başarı hissinin azalması gibi olumsuzluklara sebep olduğu belirtilmiştir (Bolat, 2011: 256). Maslach ve Leiter (1997) çalışmalarında alanyazındaki tanımlamalara yeni bir boyut kazandırarak bireylerin yaşadıkları tükenmişliğin sebebinin tek nedeni olarak çalışma ortamı görülemeyeceği, kişisel yükümlülüklerin de bireyleri tükenmişliğe sürükleyebileceğini belirtmişlerdir (Gündüz, Çapri ve Gökçakan, 2012: 39). Bireylerin yaşadığı tükenmişlik, kendilerinde yetersizlik hissi uyandırmakta, böylece birey ne kadar çabalarsa çabalasın başarılı olamayacağını düşündüğü için iş becerisinde düşüş yaşanması kaçınılmazdır. Tükenmişliğin sebebiyet verdiği bir diğer olumsuz etki ise yaptığı işte başarılı olsa dahi kendi başarısından tatmin 
olmayan kişinin motivasyonunda yaşanılan düşüştür (Ardıç ve Polatc1, 2008: 75; Maslach ve Zimbardo, 1982: 77).

Bireylerin çalışma saatleri içerisinde gerçekleştirmek sorumlu oldukları görevlerini ifade eden iş yükü kavramı (Ardıç ve Polatcı, 2009: 26; Maslach ve Leiter, 1997: 38) tükenmişliği iki farklı şekilde ortaya çıkarmaktadır. Bu kapsamda bireylerin iş yükünün fazla olması üstesinden gelinemeyecek hissiyat uyandırırken, iş yükünün az olması da gerçekleştirmesi gereken sorumlulukları ciddiye almamasına ve bu şekilde başarısız olmasına neden olur. İş yükünün vermiş olduğu stres de, bireyin yaptığ işten memnun olmamasına yol açar bu durum iş ile ilgili tatminsizliğe yol açar (Ardıç ve Polatcı, 2009: 26; Leiter, 2003: 2). Bu noktada tükenmişliğin bireylere olan etkilerine değinmek gerekir. İş hayatından tatmin olmamaya başlayan bireyler fiziksel ve zihinsel anlamda çeşitli sıkıntılar yaşayabilir ve işten ayrılma durumu gerçekleşebilir. Hatta öyle ki, sadece bulunduğu işletmeyi değil tamamen mesleğinden de vazgeçebilir. Bireylerde tükenmişlik duygusunun oluşmaması için kişiye ve kuruma yönelik çeşitli önlemler alınmalıdır. Bu kapsamda (Aslan, 2000: 432);

- Bireysel yetenekleri geliştirmeye yönelik faaliyetler gerçekleştirmek,

- Çalışma ortamında bulunan bireyler ile iletişimi güçlendirmeye yönelik becerileri geliştirmek,

- Yaşanılan durumlar karşısında olumlu bir bakış geliştirmek,

- Yaşanılan stresle başa çıkma yolları geliştirmek gibi bireysel önlemlerin yanı sıra;

- Çalışma ortamını organize etmek ve planlama yapmak,

- Yaşanılan sorununun çözümü için uygun ortamı sağlamak,

- Gelişmeleri takip ederek çalışanlara gerekli imkân sağlamak,

- Güvenli bir çalışma ortamı sağlamak,

- Geleceğe yönelik gerçekleştirilebilecek planlama yapmak,

- Çalışanlara yönelik iş yükü dengesini sağlamak,

- Çalışanların başarısını değerlendirmek gibi kurumsal önlemler de alınmalıdır.

\section{Örgütsel Bağlılık}

İnsanlar ilk çağlardan itibaren içü̈düsel olarak bir aidiyet duygusu ile hareket etmiştir ve bu duygu insanlara yaşadıkları çevrede ve çalışma ortamlarında bir gruba ya da bir duruma karşı gelişen duygusal bir gereksinim haline gelmiştir (Koç, 2009: 201). Bu durum bireylerin davranışlarını belirlemekle kalmayıp düşünce tarzlarını da şekillendirmiştir. Böylece insanların davranışlarının ve 
düşüncelerinin sonucunda gerçekleştirdikleri eylemlerin temelinde ait olma ihtiyacı yer almaktadır. Ait olma ihtiyacı, bireyleri pozitif yönde etkilemektedir ve verimli bir çalışma ortamı için temel şartlardan biridir. Çalışanlar için hayati bir konumu bulunan aidiyet duygusu "örgütsel bağlılık" kavramını ortaya çıkarmışır.

Örgütsel bağlılık kavramı hakkında kabul gören ilk çalışmalardan biri 1960 yılında Becker tarafından yapılmıştır ve bu çalışmada örgütsel bağlılık kavramının; insanların örgüt ile arasında gerçekleşen bir durum olduğunu ve bu durumun karş1lıklı gelişerek her iki tarafında birbirini desteklemesi ile gerçekleştiğini öne sürmüştür (Koç, 2009:202; Becker, 1960: 32). 1961 yılında örgütsel bağlılığa ait bir sınıflandırma yapan Etzioni, örgütsel bağlılığın bireyler ve örgüt arasında iletişimi güçlendirici bir etkisi olacağını ileri sürerek örgütsel bağlılığı; ahlaki yakınlık, çıkarcı yakınlık ve yabancılaştırıcı yakınlık üç grupta değerlendirmiştir (Gül, 2002: 43; Balay, 2000: 15-16). Kanter, 1968 yılında örgütsel bağlılığı; sürdürülebilirliğin sağlanmasına yönelik, çalışma ortamında uyum sağlanmasına yönelik ve kontrolün sağlanmasına yönelik olmak üzere üç grupta incelemiş; örgütsel bağl1lığı insanların örgütsel hedeflerini gerçekleştirmeleri için geçen süre ve bu süreçte sarf ettikleri çaba olarak tanımlamıştır (Sığrı, 2007: 263; Kanter, 1968: 500). Ardından 1979 yılına gelindiğinde Mowday, Steers ve Porter örgütsel bağl1lık kavramını, insanların tutum ve davranışlarını örgüte yönelik güçlü bir inançla şekillendirmesi ve sürdürmesi şekilde tanımlayarak tutum ve davranışsal olarak iki gruba ayırmıştır (Koç, 2009: 202; Mowday, Steers ve Porter, 1979: 225). O’Reilly ve Chatman (1986) örgütsel bağl1lık kavramını, bireylerin örgüte karşı psikolojik bağlılığı olarak tanımlamış (Sığrı, 2007: 264; O’Reilly ve Chatman, 1986: 492); 1990 yılında Allen ve Meyer, duygusal bağl1lık, devamlı bağl1lık ve normatif bağl1lık şeklinde gruplandırmıştır (Koç, 2009: 202; Meyer, Allen ve Smith, 1993: 539).

Örgütsel bağl1lık duygusu yaş, cinsiyet, eğitim seviyesi, medeni durum ve hizmet süresi gibi demografik özellikler karşısında farklılık gösterebilmektedir. Yapılan çalışmalarda yaşı ilerleyen bireylerde örgütsel bağl1lık kavramının genç bireylere oranla daha yerleşmiş bir duygu olduğu gözlemlenirken; cinsiyet faktörü için kesin bir sonuç elde edilememiştir. Bunun yanı sıra bireylerin eğitim düzeyinin artması ile örgütsel bağl1lık duygusunun azaldığı gözlemlenmiştir. Bireylerin medeni durumları ile örgütsel bağlılık arasında bir ilişki bulunmadığı ortaya çıkarken hizmet süresi ile örgütsel bağl11ık arasında uyumlu bir ilişki olacağı düşünülmektedir (Özkaya, Kocakoç ve Karaa, 2006: 79-80). Psikolojik açıdan pek çok sebebe bağlı olan örgütsel bağl1lığın oluşmasında yer alan temel bileşenleri şu şekilde sıralayabiliriz (Özdevecioğlu, 2003: 114; Mowday ve dĭ̆ 1979: 227);

- Bireyin, örgütün sahip olduğu hedeflere yönelik özverili olmak

- Bireyin, sorumluluklarını gerçekleştirmesine yönelik gayret göstermek

- Bireyin, örgütün devamlılığ için çaba göstermek. 
Genel anlamda, örgütsel bağlılı̆̆ın temelinde aidiyet duygusunun yanı sıra çalışan ve örgüt arasında bağl1lık, çaba, inanç ve sadakat gibi güçlü duygular olduğu söylenebilir. Örgütsel bağl111k temelinde barındırdığı güçlü duygular ile her zaman çalışanlar ve örgüt için olumlu sonuçlar doğuran bir kavram olmuştur (Yüceler, 2009: 449).

\section{Turizm Sektörü ve Kadın}

Sanayi Devrimi ile birlikte sürekli olarak gelişmeye devam eden toplum yapısı, başta kırsal alanlardan kentlere olan yoğun göç ile ardından ise geniş aile yapısından çekirdek aile yapısına geçiş ile değişmeye başlamıştır. Kent yaşamının kendine has sosyo-kültürel ve ekonomik zorlukları ile başbaşa kalan toplum bireyleri, giderek sorumlulukları paylaşmaya başlamıştır. Endüstriyel üretimin yanı sıra hizmet sektörünün gelişmeye başlaması ve kadınların da ailelerine ekonomik anlamda yardımcı olmanın yanı sıra toplumun şekillendirilmesi ve çağdaşlık yolunda aktif rol alma isteği sebebiyle hizmet sektörüne atılarak başarılı olmuştur. Diğer taraftan ile birlikte, çoğu gelişmiş ülke ile karşılaştırıldığında Cumhuriyetin ilan edilmesinden çok kısa süre sonra kadınların toplum içerisinde ve iş hayatındaki yerini önceleyen devrimlerin gerçekleştirilmesi ile birlikte hizmet sektöründe çalışan kadın sayısı da artmaya başlamıştır (Bayram, 2018). Türkiye'de 1980'li y1llarda gerçekleştirilen devlet teşvikleri ile hızlı bir gelişme gösteren turizm sektöründe de çeşitli iş kollarının var olması, kadınlar için de bir istihdam alanı oluşturmuştur. 21. yüzyılın ilk çeyreğini geride bırakmaya az bir zaman kala, günümüzde turizm sektöründe çalışanların çoğunun kadınlardan oluştuğu görülmektedir. Hatta kadınlar sadece çalışan olarak değil farklı nitelikteki konaklama ve yiyecek-içecek işletmeleri başta olmak üzere çeşitli turizm ile ilişkili işletmelerin girişimciliğini ya da yöneticiliğini de yapmaktadır.

Bütün bu olumlu tablonun yanı sıra, kendine özgü çalışma şartları olan turizm sektörü pek çok kadın için yarı zamanlı ya da sezonluk olarak çalışılması gereken iş olarak görülmektedir. Resmi tatiller, uzun turizm sezonu, geç saatlere kadar uzanan çalışma saatleri gibi etkenler kadınların turizm sektörüne karşı olumsuz bir alg1 yarattığı da bilinmektedir (Boyacıoğlu ve Elmas, 2019: 35). Sekiz saatlik mesai süresinin saatlerce uzaması, çalışma şartlarına bağlı olarak gelişen rahatsızlıkların yanı sıra kanunen kullanma hakkına sahip olduğu; yıllık izin, süt izni, doğum ve hastalık izinlerinin de kullanılmaz hale gelmesi sebebiyle kadın çalışanlar için turizm sektörü oldukça zorlu bir sektör olarak görülmektedir (Ertaş, 2018: 628; Çalık, 2018, 42). Az gelişmiş olan ülkelerde turizm sektöründe çalışan kadınların, istismarcı insanlarla karşı karşıya kalmakta olduğu bilinmekte; eğitim seviyesinin arttığı gelişmiş ve gelişmekte olan ülkelerde ise toplumsal yapıda olumlu değişmelere neden olan turizm sektörü, kadınlar için önemli bir istihdam sahası olarak kabul edilmektedir (Oktik, 2001: 147). Turizm sektöründe çalışan kadınların karşılaştığı bir diğer sorun ise cam tavan sendromudur. Örücü ve arkadaşlarının (2007) da belirttiği üzere cam tavan sendromu erkek yöneticilerin oluşturduğu engeller, kadın yöneticilerin oluşturduğu engeller ve kişilerin kendilerinin oluşturduğu engeller olarak değerlendirilmektedir. $\mathrm{Bu}$ kapsamda turizm sektöründe çalışan kadınlar da birbirinden farklı engellerle karşı karşıya kalmaktadır. 
Turizm sektöründe çalışanlar birtakım baskılarla mücadele ederken, diğer taraftan müşterilerin ihtiyaçlarını onları mutlu edecek şekilde karşılama sorumlulukları bulunmaktadır. Bu çalışma şartlarını zorlaştırarak, çalışanın olumlu duygularının geliştirilmesini kaçınılmaz hale getirmektedir (Güven ve Sezici, 2016: 112). Aydın Tükeltürk ve Şahin Perçin'in (2008) de değindiği üzere yatay ve dikey ayrımcılık yoluyla kadın çalışanların baskılanması ve yıldırılması sonucu mesleklerine olan inancı kaybetmesi ile sonuçlanır.

Turizm sektöründe kadın istihdamı her geçen y1l artmasına rağmen kayıt dışı çalışan kadın işgücünün fazlalığı ve kadınların sektörde kazandıkları ücretlerin düşük olması olumsuz göstergelerdir. Turizm sektöründe kadınlar çoğunlukla mutfak, karşılama, oda temizliği, servis gibi ev işlerinin bir uzantısı sayılan işlerde istihdam edilmektedirler. Bu durum kadınların tam zamanlı, kalifiye, yüksek ücretli ve yöneticilik pozisyonu olan işlerde çalışmalarının sınırlı olduğu anlamına da gelebilmektedir (Tüzünkan, 2019: 79). 2010 yılında hazırlanan Turizmde Kadın Küresel Raporu da kadınların turizmdeki işgücünde yüksek bir oran oluşturduklarını ancak alt seviyelerde çalıştıklarını, erkek çalışanlara kıyasla daha az ücret aldıklarını, turizm sektöründeki aile işletmelerindeki ücretsiz işçilerin büyük çoğunluğunu kadınların oluşturduğunu ortaya koymaktadır (Kaya, 2017: 6-7). Tüm bu unsurlar turizm sektöründe kadınların işleri ile aileleri arasındaki ilişkiye olumsuz olarak yansımakla birlikte özellikle bekâr kadınların eğitimini aldıkları ve severek başladıkları turizm sektöründeki kariyerlerinde bir süre sonra tükenmişlik yaşamalarını beraberinde getirmektedir. Özellikle sektörde kurumsal olarak nitelendirilen ancak kadın oldukları için çeşitli eşitsizliklerle karşı karşıya kalan çalışanların ilgili kuruma olan örgütsel bağlılıkları da zayıflamaktadır. Bu araştırmada da bu olgunun incelenmesi amaçlanmıştır.

\section{YÖNTEM}

Kadın çalışanların turizm sektöründeki önemi gün geçtikçe daha ön plana çıkmaktadır. Diğer taraftan hizmet sektörü olarak tanımlanan turizm sektöründe, kadınların yer aldığı departman ve görevler onları kimi zaman zorlamakta, verimlilik ve performanslarını etkilemektedir. Ayrıca genellikle toplumsal cinsiyet açısından değerlendirildiğinde, kadına yüklenen görevlerin de iş yaşamını etkilediğini söylemek mümkündür. Bu kapsamda gerçekleştirilen araştırmada, turizm sektöründe yer alan kadın çalışanların iş-aile çatışması ve tükenmişlik düzeylerinin örgütsel bağl1lıklarına olan etkilerinin incelenmesi amaçlanmıştır. Farradinna ve Halim (2016)'in araştırmalarında ifade ettiği gibi iş-aile çatışması ve tükenmişlik düzeylerinin çalışanların örgütsel bağlılıklarına etkisi bulunmaktadır. Araştırmada veri toplama aracı olarak anket tercih edilmiştir. Araştırmanın anketi dört bölümden oluşmaktadır. İlk bölümde kadın çalışanların demografik ve mesleki bilgilerini elde etmek amacıyla 7 soru bulunmaktadır. Araştırmanın ikinci bölümünde kadın çalışanların iş-aile çatışması düzeylerini ölçmek için Lambert, Hohan, Camp ve Ventura (2006) tarafından oluşturulan, Yurtseven (2008), Çakır (2011) tarafindan turizm sektöründe uygulanan ve Türkçe uyarlaması Acun (2016) tarafından yinelenen 
iş-aile çatışması ölçeği kullanılmıştır. Üçüncü bölümde ise Maslach ve Jackson (1981:102-103) tarafından geliştirilen, Türkçe geçerlilik ve güvenilirlik çalışması ise Ergin (1992) tarafindan yapılan tükenmişlik ölçeğinden yararlanılmıştır. Araştırmada diğer kullanılan ölçek ise Meyer ve Allen (1991) tarafından geliştirilen, Türkçe geçerlilik ve güvenirlik çalışması Gündoğan (2009) ve Dağlı vd. (2018) tarafından yapılan örgütsel bağlılık ölçeğidir.

Alanyazın incelendiğinde bu çalışmanın temel varsayımının iş-aile çatışması ve tükenmişlik düzeylerinin örgütsel bağl1lı̆ğ etkilediği yönündedir. Yine alanyazında, iş-aile çatışması ve tükenmişlik düzeyinin, örgütsel bağl1lık üzerinde etkisi bulunduğu görülmektedir. Ayrıca araştırma değişkenlerinden örgütsel bağl1lık, iş-aile çatışması ve tükenmişliğin de birbiriyle ilişkisi bulunmaktadır. Bu üç faktörü bir arada ele alan ve iş-aile çatışması, örgütsel bağlılık ve tükenmişlik ilişkisini inceleyen çalışmalar (Lambert vd., 2010; Carlson vd., 2012; Wang vd., (2012) bulunmakla birlikte, iş-aile çatışması ve tükenmişlik düzeylerinin örgütsel bağlılığa etkisini inceleyen çalışmalar oldukça sınırlı sayıdadır.

\section{Evren, Örneklem ve Verilerin Toplanması}

Araştırmanın evrenini, Antalya'da yer alan konaklama işletmelerinde çalışan kadın personeller oluşturmaktadır. Örneklem seçiminde kolayda örnekleme yöntemi kullanılmıştır. 10.000 ve üzeri kitlelerde \%95 güven aralığında örneklem büyüklüğü 370 olarak tespit edilmiş; araştırmada 504 katılımcıdan veri elde edilmiştir. Araştırmada uygulama aşamasında 5'li Likert tipi derecelendirme ölçeğinden oluşan üç farkl1 ölçek ve toplamda 72 ifadeden oluşan anket tekniği ile veriler elde edilmiştir. Araştırmanın verileri 2019 yılı turizm sezonunda Haziran ve Eylül ayları arasında toplanmıştır.

\section{Bulgular ve Analizler}

Araştırmada elde edilen verilerin analizi, SPSS 22 istatistik programı ile değerlendirilmiş; öncelikle katılımcıların demografik özellikleri, frekans ve yüzde dağılımları ile sunulmuştur. Araştırma kapsamında toplanan verilerin, faktör analizine uygun olup olmadığını anlamak için Kaiser-MeyerOlkin (KMO) ve Bartlett Küresellik testleri yapılmıştır. Araştırmada kullanılan anket formunu oluşturan ölçeklerin güvenilirlik düzeylerinin ölçülmesi amacıyla Cronbach's Alpha değerleri hesaplanmıştır. Ayrıca her iki ölçeği oluşturan ifadelerin, gerek yapısal anlamda gerekse anlaşılırlık düzeyinin ölçülmesi amacıyla faktör analizi gerçekleştirilmiştir. Ayrıca ölçeklerdeki ifadelerin alt boyutlar kapsamında aritmetik ortalamasına ve standart sapma değerlerine yer verilmiştir. Kadın çalışanların iş-aile çatışması ve tükenmişlik ve örgütsel bağlılık ilişkilerini belirlemek için korelasyon analizi, iş aile çatışmasıtükenmişlik düzeylerinin örgütsel bağl1lığa etkisini belirlemek için de regresyon analizinden faydalanılmıştır. Araştırmanın izleyen kısmında verilerin analizi doğrultusunda elde edilen bulgulara yer verilmiştir. 
Tablo 1. Ölçeklere İlişkin Güvenirlik Analizine İlişkin Bulgular

\begin{tabular}{|c|c|c|}
\hline Ölçek & Cronbach's Alpha & İfade Sayısı \\
\hline İş Aile Çatı̧̧ması & 0,741 & 33 \\
\hline Tükenmişlik & 0,838 & 22 \\
\hline Örgütsel Bağlılık & 0,825 & 17 \\
\hline
\end{tabular}

Verilerin faktör analizine uygunluğunun testi için KMO değerinin 0,60'ın üzerinde olmas1, Bartlett küresellik testinin ise istatistiksel olarak anlamlı çıkması gerekmektedir. Bu bağlamda İş Aile Çatışması ölçeğinin analiz sonucunda KMO değeri 0,812 olarak hesaplanmış, Bartlett küresellik testi de istatistiksel olarak anlamlı $(\mathrm{p}=0,00)$ çıkmıştır. Tükenmişlik ölçeğinin analiz sonucunda KMO değeri 0,825 hesaplanmış, Bartlett küresellik testi de istatistiksel olarak anlamlı $(\mathrm{p}=0,00)$ çıkmıştır. Örgütsel Bağl1lık ölçeğinin analiz sonucunda KMO değeri 0,866 hesaplanmış, Bartlett küresellik testi de istatistiksel olarak anlamlı $(\mathrm{p}=0,00)$ çıkmıştır. Bartlett küresellik test sonucunun anlamlı çıkması, verilerin normal bir dağılımdan geldiğini göstermektedir. Dolayısıyla bu testlerin sonuçlarına göre verilerin faktör analizi için uygun olduğu anlaşılmıştır. İş aile çatışması, tükenmişlik, örgütsel bağlılık ölçeklerine ilişkin güvenilirlik analizleri Tablo 1'de yer almaktadır. Güvenirlik analiz sonuçları Tablo 1'de incelendiğinde, genel olarak tüm ölçeklerin güvenirlik katsayısının a=0,70 ve üzeri olduğu görülmektedir.

Tablo 2. Katılımcıların Bireysel Değişkenlere Göre Dağılımına İlişkin Bulgular

\begin{tabular}{|c|c|c|c|c|c|c|c|}
\hline \multicolumn{2}{|c|}{ Bireysel Değişkenler } & \multirow{2}{*}{$\begin{array}{c}\mathbf{f} \\
39\end{array}$} & \multirow{2}{*}{$\frac{\%}{7,7}$} & \multicolumn{2}{|c|}{ Bireysel Değişkenler } & \multirow{2}{*}{$\begin{array}{c}\text { f } \\
119\end{array}$} & \multirow{2}{*}{$\frac{\%}{23,6}$} \\
\hline \multirow{4}{*}{ Yaş } & 20 Yaş Altı & & & \multirow{4}{*}{$\begin{array}{c}\text { Çalısşma } \\
\text { Süresi }\end{array}$} & 1 yildan az & & \\
\hline & 20-29 Yaş & 248 & 49,2 & & $1-5$ yil & 263 & 52,2 \\
\hline & 30-39 Yaş & 120 & 23,8 & & $6-10 \mathrm{y} 1 \mathrm{l}$ & 85 & 16,9 \\
\hline & 40-49 Yaş & 97 & 19,2 & & 10 yıldan fazla & 37 & 7,3 \\
\hline \multirow{3}{*}{$\begin{array}{l}\text { Medeni } \\
\text { Durum }\end{array}$} & Bekâr & 218 & 43,3 & \multirow{10}{*}{ Birim } & Ön Büro & 111 & 22,0 \\
\hline & Evli & 286 & 56,7 & & $F \& B$ & 62 & 12,3 \\
\hline & & & & & İnsan Kaynakları & 42 & 8,3 \\
\hline \multirow{6}{*}{$\begin{array}{c}\text { Eğitim } \\
\text { Durumu }\end{array}$} & İlköğretim & 43 & 8,5 & & Kat Hizmetleri & 84 & 16,7 \\
\hline & Lise & 133 & 26,4 & & Muhasebe & 52 & 10,3 \\
\hline & Ön Lisans & 63 & 12,5 & & Yönetim & 48 & 9,5 \\
\hline & Lisans & 245 & 48,6 & & Teknik Servis & 7 & 1,4 \\
\hline & Lisansüstü & 20 & 4,0 & & Satış-Pazarlama & 12 & 2,4 \\
\hline & & & & & Bilgi İşlem & 54 & 10,7 \\
\hline \multirow{5}{*}{$\begin{array}{c}\text { Gelir } \\
\text { Durumu }\end{array}$} & 2020 TL Alt1 & 31 & 6,2 & & Güvenlik & 32 & 6,3 \\
\hline & $2021 \mathrm{TL}-3250 \mathrm{TL}$ & 118 & 23,4 & \multirow{4}{*}{ Görev } & Üst Düzey Yönetici & 43 & 8,5 \\
\hline & $3251 \mathrm{TL}-4500 \mathrm{TL}$ & 203 & 40,3 & & Orta Düzey Yönetici & 88 & 17,5 \\
\hline & $4501 \mathrm{TL}-6000 \mathrm{TL}$ & 102 & 20,2 & & Alt Düzey Yönetici & 90 & 17,9 \\
\hline & 6001 TL Üstü & 50 & 9,9 & & Eleman & 283 & 56,1 \\
\hline
\end{tabular}


Araştırmaya turizm işletmelerinde çalışan 504 kadın iş gören katılıışırır. Katılımcıların \% 49,2' lik bir kısmının 20-29 yaş, \% 23,8'nin 30-39 yaş, \% 18,5'lik bir kısmının 40-49 yaş, \%0,8’lik bir kısmının ise 50 yaş ve üstü olduğu, medeni durumları incelendiğinde ise \% 43,3'nün bekâr, \% 56,7'sinin evli olduğu görülmektedir. Katılımcıların eğitim durumu açısından ilköğretim mezunu 43 kişi, lise mezunu 133 kişi, ön lisans mezunu 63 kişi ve lisans mezunu 245 kişi, lisansüstü eğitim mezun 20 kişi olduğu görülmektedir. Katılımcıların \% 6,2'si 2019 yılı net asgari ücret olan 2020 TL ve altı, \% 23,4'ü 20213250 TL, \% 40,3’ü 3251-4500 TL, \% 20,2'si 4501-6000 TL, \% 9,9'u ise 6001 TL ve üstü gelir düzeyine sahip olduğu görülmektedir. Kadın katılımcıların çalışma süresi 1 yıldan az çalışan katılımcıların \% 23,8 ile 119 kişi, 1-5 yıl arası \% 52,2 ile 263 kişi, \% 16,9 ile 85 kişi, \% 4,6 ile 23 kişi, \% 2,8 ile 14 kişidir. Katılımcıların çalıştıkları departmanlara bakıldığında; Ön büro departmanının \% 22,6, F\&B departmanının \%12,3, İnsan kaynakları departmanının \% 8,3, Kat Hizmetleri departmanının \% 16,7, Muhasebe departmanının \%10,3, yönetim departmanının \% 9,5, teknik servis departmanının \% 1,4, satış-pazarlama departmanının \% 2,4, bilgi işlem departmanın \% 10,7, güvenlik departmanının \% 6,3 olduğu görülmektedir. Çalıştıkları pozisyonlara bakıldığında, \% 8,5'ü üst düzey yönetici, \% 17,5'i orta düzey yönetici, \% 17,9'u alt düzey yönetici, \% 56,0’s1 eleman olarak çalışmaktadır.

Tablo 3. Medeni Durum Değişkenine Yönelik İş-Aile Çatışması, Tükenmişlik ve Örgütsel Bağlılık Farkl11ık Analizi

\begin{tabular}{|c|c|c|c|c|c|}
\hline & Medeni durum & $\mathbf{n}$ & $\overline{\mathbf{X}}$ & $\mathbf{t}$ & $\mathbf{p}$ \\
\hline \multirow{2}{*}{ İş Aile Çatışması } & Bekâr & 218 & 2,84 & \multirow{2}{*}{4,873} & \multirow{2}{*}{, 000} \\
\hline & Evli & 286 & 3,01 & & \\
\hline \multirow{2}{*}{ Tükenmişlik } & Bekâr & 218 & 2,67 & \multirow{2}{*}{$-1,942$} & \multirow{2}{*}{, 053} \\
\hline & Evli & 286 & 2,77 & & \\
\hline \multirow{2}{*}{ Örgütsel Bağlılık } & Bekâr & 218 & 3,22 & \multirow{2}{*}{3,616} & \multirow{2}{*}{,000 } \\
\hline & Evli & 286 & 3,03 & & \\
\hline
\end{tabular}

Tablo 3'de, medeni durum ile iş-aile çatışması, tükenmişlik ve örgütsel bağlılık arasındaki farklılık analizleri verilmiştir. Tablo incelendiğinde, medeni durum ile hem tükenmişlik hem de örgütsel bağlılık boyutunda istatistiksel açıdan anlamlı farklılık bulunmuştur. Evli katılımcıların bekâr katılımcılara oranla tükenmişlik boyutuna göre ortalamalarının daha yükssek olduğu, bekâr katılımcıların evli katılımcılara oranla örgütsel bağl1lık boyutuna ilişkin ortalamaların daha yüksek olduğu görülmektedir. 
Tablo 4. Yaş Değişkenine Yönelik İş-Aile Çatışması, Tükenmişlik ve Örgütsel Bağlılık Farklılık Analizi

\begin{tabular}{|c|c|c|c|c|c|}
\hline & Yaş & $\mathbf{n}$ & $\overline{\mathbf{X}}$ & $\mathbf{F}$ & $\mathbf{p}$ \\
\hline \multirow[t]{4}{*}{ İş Aile Çatışması } & 20 Yaş Altı & 39 & 2,86 & \multirow{4}{*}{13,332} & \multirow{4}{*}{,000 } \\
\hline & 20-29 Yaş & 248 & 2,99 & & \\
\hline & 30-39 Yaş & 120 & 3,02 & & \\
\hline & 40-49 Yaş & 97 & 2,73 & & \\
\hline \multirow[t]{4}{*}{ Tükenmişlik } & 20 Yaş Altı & 39 & 2,57 & \multirow{4}{*}{2,815} & \multirow{4}{*}{, 039} \\
\hline & 20-29 Yaş & 248 & 2,78 & & \\
\hline & 30-39 Yaş & 120 & 2,77 & & \\
\hline & 40-49 Yaş & 97 & 2,63 & & \\
\hline \multirow[t]{4}{*}{ Örgütsel Bağlılık } & 20 Yaş Altı & 39 & 2,82 & \multirow{4}{*}{10,970} & \multirow{4}{*}{, 000} \\
\hline & 20-29 Yaş & 248 & 3,04 & & \\
\hline & 30-39 Yaş & 120 & 3,13 & & \\
\hline & 40-49 Yaş & 97 & 3,37 & & \\
\hline
\end{tabular}

Tablo 4'de, katılımcıların yaşları ile iş-aile çatışması, tükenmişlik ve örgütsel bağlılık arasındaki farklılık analizleri verilmiştir. Tablo incelendiğinde, katılımcıların yaşları ile tüm boyutlarda istatistiksel açıdan anlamlı farklılık bulunmuştur. Bu kapsamda 30-39 yaş arası katılımcıların, diğer yaşlardaki çalışanlara göre iş-aile çatışması ortalamalarının yüksek olduğu; 20-29 yaş arası katılımcıların, diğer yaşlardaki katılımcılara göre tükenmişlik ortalamalarının daha yüksek olduğu; 40-49 yaş arası katılımcıların 20 yaş altı ve 20-29 yaş aralığındaki katılımcılara göre örgütsel bağlılık ortalamalarının daha yüksek olduğu görülmektedir.

Tablo 5. Eğitim Durumu Değişkenine Yönelik Tükenmişlik Boyutunun Farkl11ık Analizi

\begin{tabular}{|c|c|c|c|c|c|}
\hline & $\begin{array}{l}\text { Eğitim } \\
\text { Durumu }\end{array}$ & $\mathbf{n}$ & $\overline{\mathbf{X}}$ & $\mathbf{F}$ & $\mathbf{p}$ \\
\hline \multirow{5}{*}{ İş Aile Çatış̧asısı } & İlköğretim & 43 & 2,9408 & \multirow{5}{*}{1,794} & \multirow{5}{*}{, 129} \\
\hline & Lise & 133 & 2,8683 & & \\
\hline & Ön Lisans & 63 & 2,9971 & & \\
\hline & Lisans & 245 & 2,9734 & & \\
\hline & Lisansüstü & 20 & 2,9439 & & \\
\hline \multirow{5}{*}{ Tükenmişlik } & İlköğretim & 43 & 2,9609 & \multirow{5}{*}{4,548} & \multirow{5}{*}{,001 } \\
\hline & Lise & 133 & 2,6210 & & \\
\hline & Ön Lisans & 63 & 2,7915 & & \\
\hline & Lisans & 245 & 2,7199 & & \\
\hline & Lisansüstü & 20 & 3,0000 & & \\
\hline \multirow{5}{*}{ Örgütsel Bağlılık } & İlköğretim & 43 & 3,3940 & \multirow{5}{*}{3,305} & \multirow{5}{*}{,011 } \\
\hline & Lise & 133 & 3,1181 & & \\
\hline & Ön Lisans & 63 & 2,9879 & & \\
\hline & Lisans & 245 & 3,0927 & & \\
\hline & Lisansüstü & 20 & 3,1412 & & \\
\hline
\end{tabular}


Tablo 5'de, eğitim durumu ile iş-aile çatışması, tükenmişlik ve örgütsel bağl1lık arasındaki farklılık analizleri verilmiştir. Tablo incelendiğinde, eğitim durumu ile tükenmişlik ve örgütsel bağl1lık boyutlarında istatistiksel açıdan anlamlı farklılık bulunmuştur. Bu kapsamda lisansüstü eğitim düzeyine sahip katılımcıların, diğer eğitim seviyesine sahip katılımcılara oranla tükenmişlik boyutu ortalamalarının daha yüksek olduğu; ilköğretim mezunu olanların da diğer eğitim seviyesine sahip katılımcılara göre örgütsel bağl1lık düzeyi ortalamalarının yüksek olduğu görülmektedir.

Tablo 6. Gelir Değişkenine Yönelik Tükenmişlik, İş-Aile Çatışması ve Örgütsel bağlılık Boyutunun Farkl111k Analizi

\begin{tabular}{|c|c|c|c|c|c|}
\hline & Gelir Durumu & $\mathbf{n}$ & $\overline{\mathbf{X}}$ & $\mathbf{F}$ & $\mathbf{p}$ \\
\hline \multirow{5}{*}{ İş Aile Çatış̧asısı } & 2020 TL Alt1 & 31 & 3,20 & \multirow{5}{*}{10,825} & \multirow{5}{*}{, 000} \\
\hline & $2021 \mathrm{TL}-3250 \mathrm{TL}$ & 118 & 2,90 & & \\
\hline & $3251 \mathrm{TL}-4500 \mathrm{TL}$ & 203 & 3,00 & & \\
\hline & $4501 \mathrm{TL}-6000 \mathrm{TL}$ & 102 & 2,92 & & \\
\hline & 6001 TL Üstü & 50 & 2,68 & & \\
\hline \multirow{5}{*}{ Tükenmişlik } & 2020 TL Alt1 & 31 & 3,00 & \multirow{5}{*}{3,716} & \multirow{5}{*}{,005 } \\
\hline & $2021 \mathrm{TL}-3250 \mathrm{TL}$ & 118 & 2,72 & & \\
\hline & $3251 \mathrm{TL}-4500 \mathrm{TL}$ & 203 & 2,72 & & \\
\hline & $4501 \mathrm{TL}-6000 \mathrm{TL}$ & 102 & 2,79 & & \\
\hline & 6001 TL Üstü & 50 & 2,53 & & \\
\hline \multirow{5}{*}{ Örgütsel Bağlılık } & 2020 TL Alt1 & 31 & 2,92 & \multirow{5}{*}{6,057} & \multirow{5}{*}{,000 } \\
\hline & $2021 \mathrm{TL}-3250 \mathrm{TL}$ & 118 & 2,92 & & \\
\hline & $3251 \mathrm{TL}-4500 \mathrm{TL}$ & 203 & 3,22 & & \\
\hline & $4501 \mathrm{TL}-6000 \mathrm{TL}$ & 102 & 3,13 & & \\
\hline & 6001 TL Üstü & 50 & 3,17 & & \\
\hline
\end{tabular}

Tablo 6'da, gelir durumu ile iş-aile çatışması, tükenmişlik ve örgütsel bağl1lık arasındaki farklılık analizleri verilmiştir. Gelir durumu ile tüm boyutlarda istatistiksel açıdan anlamlı farklılık bulunmuştur. 2020 TL ve altı gelir düzeyine sahip katılımcıların, diğer gelir düzeyine sahip katılımcılara oranla işaile çatışması boyutu ve tükenmişlik boyutu ortalamalarının yüksek olduğu; 3251 TL-4500 TL gelir düzeyine sahip katılımcıların diğer gelir düzeylerine sahip katılımcılara oranla örgütsel bağl1lık boyutuna ilişkin ortalamaların daha yüksek olduğu görülmektedir. 
Tablo 7. Deneyim Süresi Değişkenine Yönelik İş-Aile Çatışması ve Örgütsel Bağlılık Boyutunun Farkl111k Analizi

\begin{tabular}{|c|c|c|c|c|c|}
\hline & Deneyim Süresi & $\mathbf{n}$ & $\overline{\mathbf{X}}$ & $\mathbf{F}$ & $\mathbf{p}$ \\
\hline \multirow{4}{*}{ İş Aile Çatış̧ası } & 1 yıldan az & 119 & 2,91 & \multirow{4}{*}{9,733} & \multirow{4}{*}{,000 } \\
\hline & $1-5 \mathrm{y} 11$ & 263 & 3,01 & & \\
\hline & 6-10 y1l & 85 & 2,75 & & \\
\hline & 10 yıldan fazla & 37 & 2,94 & & \\
\hline \multirow{4}{*}{ Tükenmişlik } & 1 yıldan az & 119 & 2,77 & \multirow{4}{*}{,987 } & \multirow{4}{*}{,399 } \\
\hline & $1-5$ y1l & 263 & 2,74 & & \\
\hline & 6-10 yil & 85 & 2,70 & & \\
\hline & 10 yıldan fazla & 37 & 2,60 & & \\
\hline \multirow{4}{*}{ Örgütsel Bağlılık } & 1 yıldan az & 119 & 2,88 & \multirow{4}{*}{10,763} & \multirow{4}{*}{,000 } \\
\hline & $1-5 \mathrm{y} 1 \mathrm{l}$ & 263 & 3,20 & & \\
\hline & 6-10 y1l & 85 & 3,21 & & \\
\hline & 10 yıldan fazla & 37 & 2,95 & & \\
\hline
\end{tabular}

Tablo 7'de, deneyim süresi ile tükenmişlik, iş aile çatışması, örgütsel bağl1lık arasındaki farklılık analizleri verilmiştir. Deneyim süresi ile iş-aile çatışması boyutunda ve örgütsel bağl1lık boyutunda istatistiksel açıdan anlamlı farklılık bulunmuştur. 1-5 yıl deneyim süresine sahip katılımcıların, diğer deneyim düzeylerine sahip katılımcılara oranla iş-aile çatışması boyutuna göre ortalamalarının daha yüksek olduğu, yine 6-10 yıl deneyim süresine sahip katılımcıların diğer diğer deneyim düzeylerine sahip katılımcılara oranla örgütsel bağlılık boyutuna ilişkin ortalamaların daha yüksek olduğu görülmektedir. 
Tablo 8. Departman Değişkinine Yönelik Tükenmişlik, İş-Aile Çatışması ve Örgütsel Bağl1lık Boyutunun Farklılık Analizi

\begin{tabular}{|c|c|c|c|c|c|}
\hline & Çalışılan Departman & $\mathbf{n}$ & $\overline{\mathbf{X}}$ & $\mathbf{F}$ & $\mathbf{p}$ \\
\hline \multirow{10}{*}{ İş Aile Çatışması } & Ön Büro & 111 & 3,00 & \multirow{10}{*}{10,841} & \multirow{10}{*}{, 000} \\
\hline & $F \& B$ & 62 & 2,98 & & \\
\hline & İnsan Kaynakları & 42 & 2,97 & & \\
\hline & Kat Hizmetleri & 84 & 2,95 & & \\
\hline & Muhasebe & 52 & 3,08 & & \\
\hline & Yönetim & 48 & 2,46 & & \\
\hline & Teknik Servis & 7 & 3,09 & & \\
\hline & Satış-Pazarlama & 12 & 2,83 & & \\
\hline & Bilgi İşlem & 54 & 3,01 & & \\
\hline & Güvenlik & 32 & 2,96 & & \\
\hline \multirow{10}{*}{ Tükenmişlik } & Ön Büro & 111 & 2,69 & \multirow{10}{*}{3,238} & \multirow{10}{*}{,001 } \\
\hline & $F \& B$ & 62 & 2,87 & & \\
\hline & İnsan Kaynakları & 42 & 2,82 & & \\
\hline & Kat Hizmetleri & 84 & 2,69 & & \\
\hline & Muhasebe & 52 & 2,94 & & \\
\hline & Yönetim & 48 & 2,43 & & \\
\hline & Teknik Servis & 7 & 2,85 & & \\
\hline & Satış-Pazarlama & 12 & 2,65 & & \\
\hline & Bilgi İşlem & 54 & 2,74 & & \\
\hline & Güvenlik & 32 & 2,64 & & \\
\hline \multirow{10}{*}{ Örgütsel Bağlılık } & Ön Büro & 111 & 2,95 & \multirow{10}{*}{5,667} & \multirow{10}{*}{, 000} \\
\hline & $F \& B$ & 62 & 3,08 & & \\
\hline & İnsan Kaynakları & 42 & 3,25 & & \\
\hline & Kat Hizmetleri & 84 & 3,07 & & \\
\hline & Muhasebe & 52 & 3,14 & & \\
\hline & Yönetim & 48 & 3,57 & & \\
\hline & Teknik Servis & 7 & 3,31 & & \\
\hline & Satı̧s-Pazarlama & 12 & 2,84 & & \\
\hline & Bilgi İşlem & 54 & 2,97 & & \\
\hline & Güvenlik & 32 & 3,14 & & \\
\hline
\end{tabular}

Tablo 8'de, katılımcıların çalıştıkları departman ile iş-aile çatışması, tükenmişlik ve örgütsel bağlılık arasındaki farklılık analizleri verilmiştir. Çalışılan departman ile tüm boyutlarda istatistiksel açıdan anlamlı farklılık bulunmuştur. Teknik servis departmanında çalışan katılımcıların, diğer departmanlarda çalışanlara göre iş-aile çatışması boyutuna göre ortalamalarının daha yüksek olduğu; Muhasebe departmanında çalışan katılımcıların diğer departmanlarda çalışanlara göre tükenmişlik düzeyi ortalamalarının yüksek olduğu; yönetim departmanında çalışan katılımcıların ise, diğer 
departmanlarda çalışan katılımcılara göre örgütsel bağl1lık boyutuna ilişkin ortalamaların daha yüksek olduğu görülmektedir.

Tablo 9. Yönetim Yer Alma Düzeyleri Değişkinine Yönelik Tükenmişlik, İş-Aile Çatışması ve Örgütsel Bağl1lık Boyutunun Farklılık Analizi

\begin{tabular}{|c|c|c|c|c|c|}
\hline & Yönetimde Yer Alma & $\mathbf{n}$ & $\overline{\mathbf{X}}$ & $\mathbf{F}$ & $\mathbf{p}$ \\
\hline \multirow{4}{*}{ İş Aile Çatışması } & Üst Düzey Yönetici & 43 & 2,50 & \multirow{4}{*}{29,180} & \multirow{4}{*}{, 000} \\
\hline & Orta Düzey Yönetici & 88 & 2,85 & & \\
\hline & Alt Düzey Yönetici & 90 & 3,10 & & \\
\hline & Eleman & 283 & 2,99 & & \\
\hline \multirow{4}{*}{ Tükenmişlik } & Üst Düzey Yönetici & 43 & 2,31 & \multirow{4}{*}{11,307} & \multirow{4}{*}{, 000} \\
\hline & Orta Düzey Yönetici & 88 & 2,89 & & \\
\hline & Alt Düzey Yönetici & 90 & 2,72 & & \\
\hline & Eleman & 283 & 2,75 & & \\
\hline \multirow{4}{*}{ Örgütsel Bağlılık } & Üst Düzey Yönetici & 43 & 3,36 & \multirow{4}{*}{3,061} & \multirow{4}{*}{,028 } \\
\hline & Orta Düzey Yönetici & 88 & 3,09 & & \\
\hline & Alt Düzey Yönetici & 90 & 3,04 & & \\
\hline & Eleman & 283 & 3,10 & & \\
\hline
\end{tabular}

Tablo 9'da, yönetim düzeyleri ile iş-aile çatışması, örgütsel bağl11ık arasındaki farklılık analizleri verilmiştir. Çalışanların yönetim düzeyleri ile ilgili tüm boyutlarda istatistiksel açıdan anlamlı farklılık bulunmuştur. Alt düzey yöneticilerin diğer düzeydeki yöneticilere göre iş-aile çatışması ortalamalarının daha yüksek olduğu; Orta düzey yöneticilerin diğer düzeydeki yöneticilere göre tükenmişlik boyutu ortalamalarının daha yüksek olduğu ve üst düzey yöneticilerin diğer düzeydeki yöneticilere göre örgütsel bağl1lık ortalamalarının daha yüksek olduğu görülmektedir. 
Tablo 10. İfadelere Katılım Düzeylerine İlişkin Bulgular

\begin{tabular}{|c|c|c|c|c|}
\hline \multicolumn{3}{|l|}{ İfade } & $\overline{\mathbf{X}}$ & SS \\
\hline \multirow{33}{*}{ 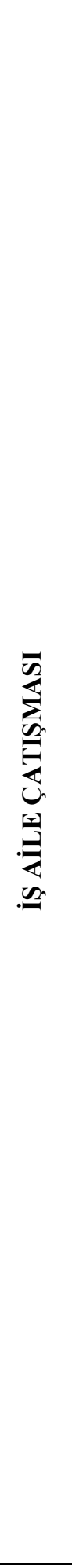 } & 1 & İşim nedeniyle ailemle geçirdiğim zamandan zevk alamıyorum. & 2,59 & 1,22 \\
\hline & 2 & İşimden dolayı aileme zaman ayıramıyorum. & 2,79 & 1,89 \\
\hline & 3 & Aile hayatım işime engel olmuyor. & 3,08 & 1,36 \\
\hline & 4 & Genellikle ailemle işim yüzünden tartışıyoruz. & 2,27 & 1,21 \\
\hline & 5 & İş dışındaki zamanım, aile bireylerimin programlarıyla uyuşuyor. & 3,01 & 1,28 \\
\hline & 6 & Sosyal hayatım işime engel olmuyor. & 2,97 & 1,29 \\
\hline & 7 & İşten eve geldiğimde genellikle yorgun olduğum için aileme eşlik edemiyorum. & 2,91 & 1,21 \\
\hline & 8 & İş dışındaki zamanım, sosyal ihtiyaçlarıma ayırdığım zamanla uyuşuyor. & 3,14 & 1,13 \\
\hline & 9 & $\begin{array}{l}\text { İşten eve geldiğimde genellikle yorgun olduğum için arkadaşlarıma eşlik } \\
\text { edemiyorum. }\end{array}$ & 2,96 & 1,15 \\
\hline & 10 & İstemediğim halde genellikle fazla mesai yapmak zorunda kalıyorum. & 2,85 & 1,19 \\
\hline & 11 & Bazen aile hayatımdaki sorunlar işe geç kalmama neden oluyor. & 2,43 & 1,25 \\
\hline & 12 & İş yerimdeki sorunları genellikle eve yansıtmıyorum. & 2,96 & 1,36 \\
\hline & 13 & İşte çok fazla zaman geçirdiğim için evimde zaman geçiremiyorum. & 3,07 & 1,73 \\
\hline & 14 & $\begin{array}{l}\text { İş̧ yerinde öğrendiğim davranışlar, daha iyi bir ebeveyn, eş, arkadaş vs. olmamda } \\
\text { bana yardımcı oluyor. }\end{array}$ & 2,98 & 1,13 \\
\hline & 15 & $\begin{array}{l}\text { İş ile ilgili sorumluluklar nedeniyle evde yapmaktan keyif aldığım şeyleri } \\
\text { yapamayacak kadar stresli oluyorum. }\end{array}$ & 2,56 & 1,04 \\
\hline & 16 & İşs saatlerimdeki belirsizlik sosyal hayatımı olumsuz etkilemiyor. & 3,35 & 1,19 \\
\hline & 17 & Evdeki stres nedeniyle iş yerinde genellikle ailevi sorunlarla meşgul oluyorum. & 2,32 & 1,15 \\
\hline & 18 & İşim yüzünden genellikle evde sinirli oluyorum. & 2,59 & 1,16 \\
\hline & 19 & İş saatlerimdeki belirsizlik aile yaşantımı olumsuz etkilemiyor. & 3,23 & 1,24 \\
\hline & 20 & Evde yapmak zorunda olduğum şeyler yüzünden, işte genellikle yorgun oluyorum. & 2,57 & 1,16 \\
\hline & 21 & İşim aile hayatımı olumlu yönde etkiliyor. & 3,15 & 1,23 \\
\hline & 22 & $\begin{array}{l}\text { Evde üstlendiğim roller (ebeveyn, eş, vb.) iş yerinde üstlendiğim roller ile } \\
\text { çatı̧mıyor. }\end{array}$ & 3,02 & 1,17 \\
\hline & 23 & İşim, işten uzak kaldığım zamanlarda bile rahat olmamı zorlaştırıyor. & 2,85 & 1,11 \\
\hline & 24 & İşimden dolayı özel yaşantıma ayıracağım zamanım olmuyor. & 2,80 & 1,09 \\
\hline & 25 & İş ve aile yaşantımı dengelemeye çalışırken kendimi gergin hissetmiyorum. & 3,25 & 2,17 \\
\hline & 26 & Bazen sosyal hayatımdaki sorunlar işe geç kalmama neden oluyor. & 2,61 & 1,19 \\
\hline & 27 & Ailem, işimde geçirdiğim zamandan dolayı mutlu olduklarını ifade ediyor. & 3,26 & 1,12 \\
\hline & 28 & Çoğu zaman işimden dolayı ailemle ilgili önemli olayları kaçırıyorum. & 2,91 & 1,05 \\
\hline & 29 & Arkadaşlarım işimde geçirdiğim zamandan dolayı mutlu olduklarını ifade ediyorlar. & 3,23 & 1,04 \\
\hline & 30 & Evde sergilediğim davranışların iş yerinde etkili olmadığını fark ediyorum. & 3,19 & 1,04 \\
\hline & 31 & Ailem sürekli işimle meşgul olmamdan hoşlanıyor. & 3,39 & 1,09 \\
\hline & 32 & Çoğu zaman işimden dolayı sosyal hayatımla ilgili önemli olayları kaçırıyorum. & 3,02 & 1,09 \\
\hline & 33 & Arkadaşlarım sürekli işimle meşgul olmamdan hoşlanıyorlar. & 3,39 & 1,08 \\
\hline \multirow{4}{*}{ 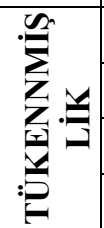 } & 1 & Mesleğimden soğuduğumu hissediyorum. & 2,21 & 1,14 \\
\hline & 2 & İş dönüşü kendimi ruhen tükenmiş hissediyorum. & 2,46 & 1,21 \\
\hline & 3 & Sabah kalktığımda bir daha bu işi kaldıramayacağımı hissediyorum. & 2,40 & 1,21 \\
\hline & 4 & Mesleğim gereği karşılaştığım bazı kimselere kötü davrandığımı fark ediyorum. & 2,34 & 1,19 \\
\hline
\end{tabular}




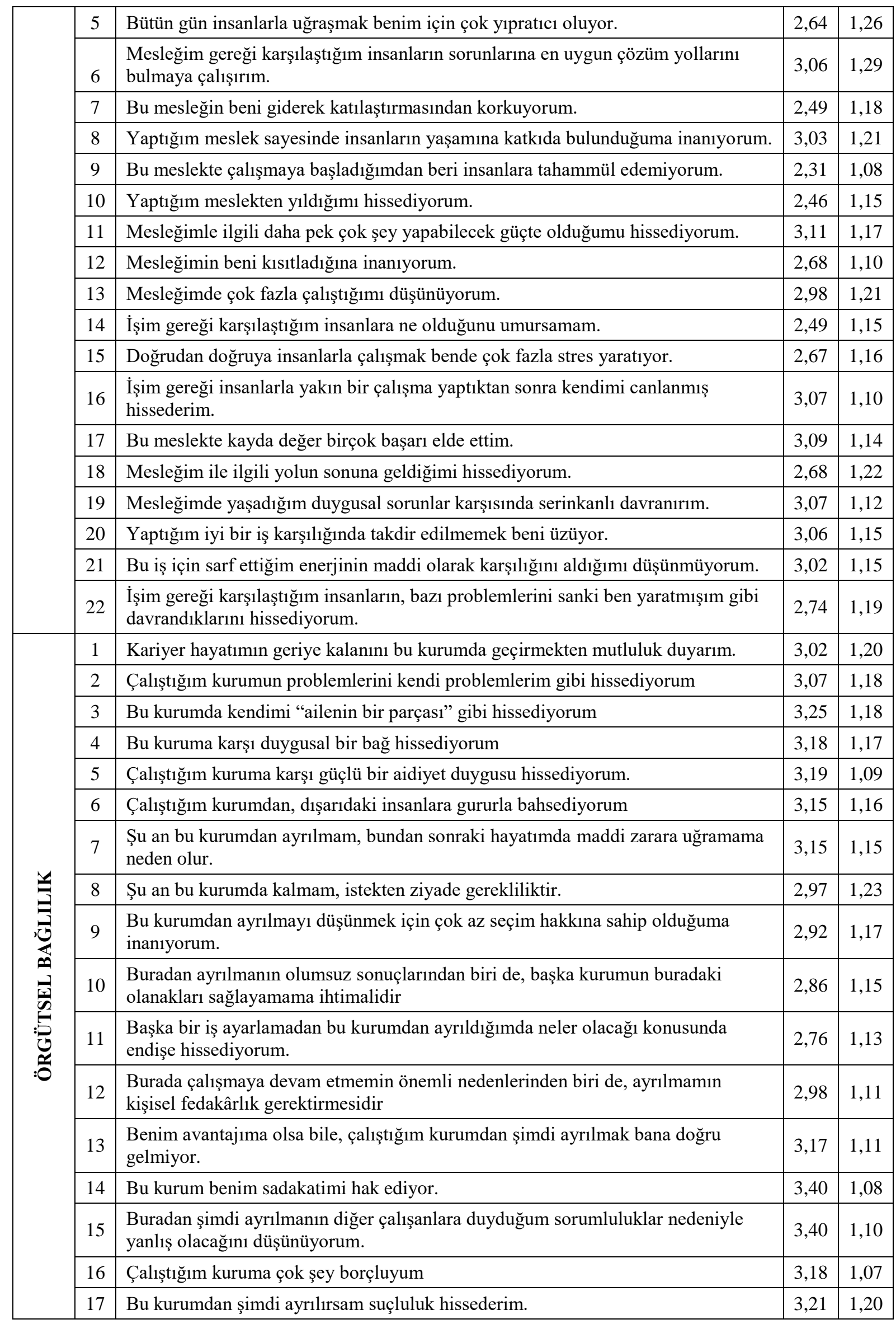


Tablo 10'da kadın iş görenlerin iş aile çatışması, tükenmişlik, örgütsel bağlılık algılarına ilişkin bazı tanımlayıcı istatistikler yer almaktadır. Tablo incelendiğinde, çalışanların iş-aile çatışması, tükenmişlik ve örgütsel bağl1lık algılarının ortalama düzeyde olduğu tespit edilmiştir. Tablodan hareketle iş aile çatışması ölçeğinde; en yüksek ifadenin "Çoğu zaman işimden dolayı sosyal hayatımla ilgili önemli olayları kaçırıyorum (3,09)", Tükenmişlik ölçeğinde "Mesleğimde yaşadı̆̆ım duygusal sorunlar karşısında serinkanlı davranırım $(3,11)$ ”, Örgütsel bağl1lık ölçeğinde ise "Bu kurum benim sadakatimi hak ediyor $(3,19)$ " olduğu görülmektedir.

Tablo 11. İş Aile Çatışması, Tükenmişlik ve Örgütsel Bağl1lık Arasındaki İlişkiye Yönelik Korelasyon Analizi Sonuçları

\begin{tabular}{|c|c|c|c|c|}
\hline & & İş Aile Çatış̧ması & Tükenmişlik & Örgütsel Bağlılık \\
\hline \multirow{3}{*}{$\begin{array}{l}\text { İş Aile } \\
\text { Çatışması }\end{array}$} & Pearson Correlation & 1 &, $370^{* *}$ &,$- 247^{* *}$ \\
\hline & Sig. (2-tailed) & & ,000 &, 000 \\
\hline & $\mathrm{N}$ & 504 & 504 & 504 \\
\hline \multirow{3}{*}{ Tükenmişlik } & Pearson Correlation & $370^{* *}$ & 1 &,- 069 \\
\hline & Sig. (2-tailed) & 000 & &, 123 \\
\hline & $\mathrm{N}$ & 504 & 504 & 504 \\
\hline \multirow{3}{*}{$\begin{array}{l}\text { Örgütsel } \\
\text { Bağlıllık }\end{array}$} & Pearson Correlation &,$- 247^{* *}$ &,- 069 & 1 \\
\hline & Sig. (2-tailed) &, 000 &, 123 & \\
\hline & $\mathrm{N}$ & 504 & 504 & 504 \\
\hline
\end{tabular}

Tablo 11'de iş-aile çatışması, tükenmişlik ve örgütsel bağlılık arasındaki ilişkiye yönelik korelasyon sonuçları görülmektedir. Tablo incelendiğinde, iş-aile çatışması ile tükenmişlik boyutu arasında istatistiki açıdan pozitif yönlü anlamlı bir ilişkiye $(, 459)$ rastlanılmıştır. İş- aile çatışması ile örgütsel bağl1lık boyutu arasında ise pozitif yönlü zayıf bir ilişkiye $(, 108)$ rastlanılmıştır. Tükenmişlik boyutu ile örgütsel bağl1lık boyutu arasında da istatistiki açıdan anlamlı bir ilişki bulunamamıştır. Buradan hareketle iş-aile çatışması içerisinde olan katılımcıların, tükenmişlik boyutuna ve örgütsel bağlılık düzeyine ilişkin ortalamasını da arttırabileceği söylenebilir.

Tablo 12. İş-Aile Çatışmasının Örgütsel Bağl1lık Üzerindeki Etkisine Yönelik Regresyon Analizi

\begin{tabular}{|l|c|c|c|c|c|c|}
\hline Bağımsız Değişken & $\mathbf{B}$ & $\mathbf{S}\left(\mathbf{b}_{\mathbf{j}}\right)$ & $\mathbf{t}$ & $\mathbf{P}$ & $\mathbf{R}^{\mathbf{2}}$ & $\mathbf{F}$ \\
\hline Sabit & 2,595 &, 160 & 16,241 &, $000^{*}$ & \multirow{2}{*}{, 058} & \multirow{2}{*}{$\mathrm{F}=7,192$} \\
\cline { 1 - 5 } İş Aile Çatışması &, 152 &, 057 & 2,682 &, 008 & & \\
\hline
\end{tabular}

Bağımlı Değişken: Örgütsel Bağlılık *: $\mathrm{p}<0,01$

Tablo 12'de görüldüğü üzere, iş-aile çatışmasının örgütsel bağl111k üzerinde 0,01'lik düzeyde anlamlı bir etkisinin olduğu belirlenmiştir. Buna göre iş-aile çatışmasında meydana gelen her 1 puanlık artışın, örgütsel bağl1lık üzerinde “,152” puanlık bir yükselişe neden olduğu görülmektedir. Elde edilen $\mathrm{T}$ değerinin her düzeyde anlamlılık göstermesi (Sig.= ,008), iş-aile çatışması değişkeninin anlamlı bir 
katsayıya sahip olduğunu göstermektedir. Ayrıca iş-aile çatışması, örgütsel bağl1lığın \%5.8'ini açıklamaktadır. Elde edilen bilgiler doğrultusunda, "iş-aile çatışmasının örgütsel bağlılık üzerinde anlamlı bir etkisinin olduğu" görülmektedir.

\section{SONUÇ ve DEĞERLENDİRME}

Bir konaklama işletmesi veya restoran mutfağında yemek üretim aşamasından, servis aşamasına; turizm işletmelerinin yönetim ve pazarlama birimlerinde; konaklama işletmelerinin kat hizmetleri, çamaşırhane, servis, resepsiyon vb. birimlerinde istihdam edilen tüm kadın çalışanların iş ile ilgili olarak yaşadıkları sorunların belirlenmesi, bu sorunların başta aile hayatları olmak üzere genel anlamda turizm sektöründe çalışma düşüncelerine nasıl yansıdığının ortaya konulması önemlidir. Öyle ki, bütün toplumlarda olduğu gibi Türk toplum yapısının şekillenmesinde de kadının her alanda yeri büyüktür. Türkiye Cumhuriyeti Devleti'nin kurucusu Gazi Mustafa Kemal Atatürk; "Dünyada her şey kadının eseridir. Kadınlarını geri bırakan toplumlar geride kalmaya mahkûmdur", sözü ile hem toplum içerisinde hem de çalışma hayatı içerisinde kadınların ve kadın işgücünün mutlaka var olması gerekliliğini vurgulamıştır.

$\mathrm{Bu}$ çalışma ise turizm sektörünün önemli bir bileşeni olan konaklama işletmelerindeki kadın çalışanların iş-aile çatışması ve tükenmişlik düzeylerinin örgütsel bağlılıkları üzerinde bir etki gösterip göstermediğini incelemek amacıyla gerçekleştirilmiştir. Alanyazın incelendiğinde turizm dışındaki diğer hizmet sektörleri başta olmak üzere, son yıllarda turizm sektöründe istihdam edilen kadın çalışanlara yönelik çalışmaların da arttığı görülmektedir. Diğer taraftan bu çalışmada sadece kadın çalışanların farklı değişkenleri üzerinden elde edilen verilerin incelenmesi ve sonuçlara ulaşılması alanyazın kapsamında da önemlidir.

Araştırma bulgularından hareketle evli kadınların iş-aile çatışmasını daha fazla yaşadıkları görülmektedir. Toplum içerisindeki rolleri ile iş yaşamına ilişkin konuların evli kadınlarda böyle bir durum ortaya çıkardığı söylenebilir. Diğer taraftan ise evli kadın çalışanların örgütsel bağlılık düzeyinin bekâr olanlara nispeten daha yüksek olduğu da görülmüştür. Bu kapsamda hem evli olmasından dolay1 farklı işletmelerde çalışmanın getireceği bilinmezlik ve zorluklarla birlikte işletme yönetiminin davranışlarını özümseyerek değerlendirmeleri, evli kadın çalışanların bu tutum içerisinde olduğunun göstergesi olarak değerlendirilebilir. Katılımcılar yaşları bakımından değerlendirildiğinde 30-39 yaş arasında olan kadın çalışanların iş-aile çatışması düzeyinin yüksek olduğu görülmekte, 20-29 yaş kadın çalışanların ise tükenmişlik düzeyinin yüksek olduğu görülmektedir. Mesleki anlamda birkaç yılı geride bırakmış olmasına rağmen yaşları gereği evlilikleri veya çocukları nedeniyle yoğun iş yaşamının gerektirdikleri nedeniyle bu yaş aralığındaki kadınların iş-aile çatışmasını yüksek düzeyde yaşadığı söylenebilirken; henüz mesleğe yeni atılmış ve kendi özel hayatlarını yeni kurma aşamasında olan kadın çalışanların da sektörden beklentileri ile karşılaştıkları arasındaki seviyenin birbirinden farklı olması onları tükenmiş̧liğe itebilir. Bunun yanında 40-49 yaş arasındaki kadın çalışanların da örgütsel bağlılığı 
en yüksek düzeyde olan kesim olması, meslekte tecrübe ve yaşlarının getirdiği olgunluğun verilere yansıması olarak değerlendirilebilir.

Eğitim seviyesi lisans düzeyinde olan çalışanların iş-aile çatışması daha yüksek düzeyde iken, lisansüstü eğitim almış personel kendini mesleki anlamda daha fazla tükenmiş hissetmektedir. İlköğretim seviyesinde eğitim alan kadın personelin ise örgütsel bağl1lı̆̆ en yüksektir. Bu durum esasında önemli bir noktaya dikkat çekmektedir. Eğitim seviyesi düşük olan kadın çalışanlar, çalıştıkları işletmenin kendisine sunduğu olumlu firsatları içselleştirerek, işletmeyi kendi işletmesi gibi görürken diğer taraftan ise bu işletmeden ayrıldığında başka bir işletmede iş bulamayacağı fikrinde de olabilir. $\mathrm{Bu}$ konuda daha net verilere alanda gerçekleştirilecek nitel yöntem araştırmalar ile ulaşılabilir.

2019 yılı asgari ücreti net 2020 Türk lirasıdır. Bu kapsamda 2020 tl. ve altında maaş alan kadın çalışanların yarı zamanlı veya saatlik çalışanlar olduğu düşünülür ise iş-aile çatışmasının yüksek olduğu görülmektedir. Özellikle çalışmaları karşıllğında ev işlerinden, çocuklarının ve ailelerinin bakımından ferâgat eden kadınlara yönelik toplum içerisinde; "Ne gerek var!", "Yaptığın iş aldığın maaşa değmiyor ki!"; "Çalışmak yerine evinde çocuklarına bakman daha iyi olur!" gibi düşünceler, kadın çalışanların işaile çatışmasının en temel çıkış noktasıdır. Sonuçlardan elde edilen bir diğer bulgu ise düşük gelire sahip kadın çalışanlarda tükenmişliğin de yüksek olduğudır. Turizm işletmelerinde bu kategori içinde yer alan kadın çalışanlar için çalışma şartları düzenlenirken, söz konusu iki faktör arasında görülen pozitif yönlü korelasyon da dikkate alınmalıdır.

Deneyim süresi 1-5 yıl olan çalışanlarda iş-aile çatışmasının ve tükenmişlik düzeyinin daha fazla olduğu ancak bu zaman aralığında çalışanlar ile 6-10 yıl arası tecrübeye sahip olanların da örgütsel bağl11ı̆̆ının daha yüksek olduğu görülmektedir. Departmanlar göz önüne alındığında ise teknik, servis, muhasebe, bilgi işlem ve önbüro gibi bölümlerde iş-aile çatışmasının daha yüksek olduğu; muhasebe, f\&b ve teknik servis bölümlerinde tükenmişliğin daha yüksek olduğu; yönetim, insan kaynaklar1 ve güvenlik gibi bölümlerde de örgütsel bağl1lığın en yüksek düzeyde olduğu görülmektedir. Yaptıkları işin niteliği, gün içindeki zorlukları, müşteriler ve yönetim tarafından karşılaştıkları durumlar kadın çalışanların departmanlara göre iş-aile çatışması, tükenmişlik ve örgütsel bağl1lığ farklı değerlendirmelerini beraberinde getirmektedir. Alt düzey yöneticilerin iş-aile çatışmasına daha çok maruz kaldığı, orta düzey yöneticilerin ise tükenmişlik düzeylerinin yüksek olduğu görülmekle birlikte üst düzey yönetici olarak çalışan kadınların örgütsel bağlılığının yüksek olduğu görülmektedir. $\mathrm{Bu}$ durum konaklama işletmelerinde kadın çalışanların alt seviyede yoğun plan ve program ve iş bölümü ile sorumluluklarının ve üst yönetime hesap verme yükümlülüklerinden kaynaklandığı söylenebilir.

İş-aile çatışmasının kadın çalışanlarda orta düzeyde bir tükenmişlik yarattığı görülmüştür. Ancak iş-aile çatışmasının kadın çalışanların örgütsel bağlılığını çok zayıf bir şekilde etkilediği görülmüştür. $\mathrm{Bu}$ sonuç oldukça önemlidir. Çünkü kadınların çalıştıkları işletmeye yönelik bağl1lıklarının iş-aile çatışmasından etkilenmemesi, işletmeler için önemli bir sonuçtur. Bu noktada işletmeler kadın 
çalışanların daha çok tükenmişlik duygusu içerisinde olmalarına neden olan etkenleri ortadan kaldırmakla mücadele etmesi gerektiği görülmektedir.

Özellikle turizm sektöründe insan emeğinin yoğun kullanılmasının yanında sektörün kendine özgü pek çok zorlukları ile toplumda kadına yönelik bakış açısında var olan bazı tutumlar, kadın çalışanların işleri ile ilgili görev ve sorumlulukları yerine getirirken oldukça zorlanmasına neden olmaktadır. Öyle ki, 2000’li yıllara kadar turizm sektöründe kadın çalışanların istihdam edilmesinden ziyade otelcilik ve turizm meslek liseleri ile lisans düzeyinde eğitim veren üniversitelerde dâhi erkek öğrencilerin daha fazla olduğu bir dönem söz konusu iken; günümüzde kadın çalışanların sektörde ve akademideki rolü ve önemi oldukça büyüktür. Çalıştıkları kurumda mesleki tecrübesinin yanı sıra alanı ile ilgili eğitim düzeyi akademik anlamda olmasa dâhi kadınların estetik ve sanatsal bakış açısından, hayal güçlerinden faydalanılmasının işletmeye oldukça faydası olacaktır.

Turizm sektörünün genelinde yoğun çalışma saatleri, herkesin tatil yaptığı özel günlerde çalışılmak zorunda kalması gibi nedenler; kadınların evlenip aile kurmasına; evli kadınların çocuk sahibi olmasına, çocuklu kadınların ise çocukları ile ilgilememesi gibi sorunlar yaşamasına da neden olmaktadır. Kadın çalışanların işletmeye olan bağlılı̆̆ını, iş ile ilgili motivasyonunu olumlu anlamda etkilemek için bu çerçevede yönetimsel değişiklikler yapılması, kadın olmanın gerektirdiği toplumsal sorumlulukları yerine getirmesi adına kolaylıklar sağlanması gerekmektedir. Bu unsurlar işletme yönetimi tarafından değerlendirildiğinde ve gerekli düzenlemeler yapıldığında işletmenin kârlılık ve iş verimliliği de artacaktır.

İşletme yöneticileri tarafından eğitim seviyeleri ilkokul, ortaöğretim veya önlisans seviyesinde olan kadın çalışanlara meslekte kendilerini geliştirmeleri açısından farklı eğitimler verilmesi, onların iş ve aileleri arasındaki çatışmalar başta olmak üzere tükenmişlik konusuna daha bilimsel çözümler kazandırabilir. Kadınların sürekli gelişme çerçevesinde ulusal ve uluslararası düzeyde sektörel eğitimler veya çeşitli etkinliklere katılmasının desteklenmesi işletmeler için olduğu kadar toplum içerisinde eşitliğin sağlanması adına önem taşımaktadır.

\section{KAYNAKÇA}

Acun, S. (2016). IŞ-aile çatışması ve turist rehberlerinin gözden kaybolmasına nedenlerine etkisi. Balıkesir Üniversitesi S.B.E. Yayınlanmamış yüksek lisans tezi, Balıkesir.

Ardıç, K. ve Polatçı, S. (2008). Tükenmişlik sendromu akademisyenler üzerinde bir uygulama (GOÜ örneği). Gazi Üniversitesi İktisadi ve İdari Bilimler Fakültesi Dergisi, 10 (2).

Ardıç, K. ve Polatçı, S. (2009). Tükenmişlik sendromu ve madalyonun öbür yüzü: İşle bütünleşme. Erciyes Üniversitesi İktisadi ve İdari Bilimler Fakültesi Dergisi, (32), 21-46.

Aslan, H. (2000). Hekimlerde tükenme sendromu ve önleme yolları. Kahramanmaraşs Sütçü İmam Üniversitesi Tip Fakültesi Psikiyatri ABD, Arşiv, 9, 427-436. 
Aydın Tükeltürk, Ş. ve Şahin Perçin, N. (2008). Turizm sektöründe kadın çalışanların karşılaş̧ıkları kariyer engelleri ve cam tavan sendromu: Cam tavanı kırmaya yönelik stratejiler. Yönetim Bilimleri Dergisi 6 (2), 113-128.

Balay, R. (2000). Özel ve resmi liselerde yönetici ve ögretmenlerin örgütsel bağllll̆ğl: Ankara ili örneği, Ankara Üniversitesi Sosyal Bilimler Enstitüsü, Yayınlanmamış Doktora Tezi, Ankara.

Bayram, A.T. (2018), Turizm Sektöründe Girişimci Olarak Kadın, Erkol Bayram, G., Bayram, A.T. ve Altunöz Sürücü, Ö. (Ed.), Turizm ve Kadın içinde (s. 51-67). Detay Yayıncılık, Ankara.

Becker, Howard S. (1960). Notes on the concept of commitment. The American Journal of Sociology, 66, $32-40$.

Bolat, O. İ. (2011). Öz yeterlilik ve tükenmişlik ilişkisi: Lider-üye etkileşiminin aracıllk etkisi. Ege Akademik Dergisi, 11(2), 255-266.

Boyacığolu, E. Z. ve Elmas, Ç. (2019), Turizm ve kadın olgusunun bibliyometrik yaklaşım ile incelenmesi. Seyahat ve Otel Işsletmeciliği Dergisi, 17(1), 32-52.

Carlson, D., Ferguson, M., Hunter, E., ve Whitten, D. (2012). Abusive supervision and work-family conflict: The path through emotional labor and burnout. The Leadership Quarterly, 23(5), 849-859.

Çakır, M. (2011) Turizm sektöründe iş-aile çatışması: Ankara'daki 4 ve 5 yıldızlı otel işletmelerinde bir araştırma. Gazi Üniversitesi Eğitim Bilimleri Enstitüsü, Yayımlanmamış Yüksek Lisans Tezi, Ankara.

Çalık, A.Ö. (2018). Turizm sektöründe kadın istihdamı. Erkol Bayram, G., Bayram, A.T. ve Altunöz Sürücü, Ö. (Ed.), Turizm ve Kadın içinde (s. 31-48). Detay Yayıncılık, Ankara.

Çarıkçı, H.İ. ve Çelikkol, Ö. (2009). İş-aile çatışmasının örgütsel bağlılık ve işten ayrılma niyetine etkisi. Süleyman Demirel Üniversitesi Sosyal Bilimler Enstitüsü Dergisi, 9, 153-170.

Dağl1, A., Elçiçek, Z. ve Han, B. (2018). Örgütsel bağlllık ölçeği'nin türkçeye uyarlanması: geçerlik ve güvenirlik çalışması. Elektronik Sosyal Bilimler Dergisi. 17 (68), 1765-1777.

Diker, O. (2010). İş-aile çatışması ve işe bağlllık ilişsisinin turizm sektöründe incelenmesi: Nevşehir bölgesinde faaliyet gösteren beş ylldızlı otel çalışanları üzerinde bir araştırma, Nevşehir Üniversitesi SBE, Yayımlanmamış Yüksek Lisans Tezi, Nevşehir.

Ergin, C. (1992). Doktor ve hemşirelerde tükenmişlik ve maslach tükenmişlik ölçeğin uyarlanması", VII. Ulusal Psikoloji Kongresi Bilimsel Çalışmaları El Kitabı,143-154

Ertaş, Ç. (2018). Otellerde çalışan erkeklerin kadınların çalışmasına karşı tutumu: Erilliğin etkisi. Iş̧letme Araştırmaları Dergisi, 4 (10), 625-645.

Farradinna, S., \& Halim, F. W. (2016). The consequences of work-family conflict, burnout and organizational commitment among women in Indonesia. Procedia-Social and Behavioral Sciences, 219, 241-247.

Genç, N. (2004). Yönetim ve Organizasyon. Seçkin Basım. Ankara, 2004.

Greenhaus, J.H. ve Beutell, N.J. (1985). Sources of conflict between work and family roles. The Academy of Management, 10 (1), 76-88.

Gül H., (2002). Örgütsel bağlllık yaklaşımlarının mukayesesi ve değerlendirilmesi. Ege Academic Review, 2 (1), 37-55. 
Gündoğan, T. (2009). Örgütsel bağlllı: Türkiye Cumhuriyet Merkez Bankası uygulaması. Türkiye Cumhuriyet Merkez Bankası, İnsan Kaynakları Genel Müdürlüğü, Uzmanlık Tezi, Ankara.

Gündüz, B., Çapri, B. ve Gökçakan, Z. (2012). Üniversite öğrencilerinin tükenmişlik düzeylerinin incelenmesi. Dicle Üniversitesi Ziya Gökalp Eğitim Fakültesi Dergisi, (19), 38-55.

Güven, Ö.Z., Sezici, E. (2016). Otel işletmelerinde işgörenlerin tükenmişlik düzeylerinin maslach tükenmişlik modeline göre incelenmesi. Yönetim ve Ekonomi Araştırmaları Dergisi, 14(2), 111- 132.

Kanter, R.M. (1968). Commitment and social organization: A study of commitment mechanisms in utopian communities., American Sociological Review, 33(4), 499-517.

Kaya, Ş. (2017). Turizmde Kadın Emeği. Karatahta Işs Yazıları Dergisi, 9, s. 1-22.

Koç, H. (2009). Örgütsel Bağl1lık ve Sadakat İlişkisi. Elektronik Sosyal Bilimler Dergisi, 8(28), 200-211.

Lambert, E. G., Hogan, N. L., Camp, S. D. ve Ventura, L. A. (2006). The impact of work-family conflict on correctional staff: A preliminary study. Criminology \& Criminal Justice, 6(4), 371-387.

Leiter, M. P. (2003). Areas of worklife survey manual (third edition), Centre for Organizational Research and Development, Wolfville, Canada.

Maslach, C. ve Zimbardo P.G. (1982). Burnout -the cost of caring, Prentice-Hall, Inc., Englewood Cliffs, New Jersey.

Maslach, C., ve Jackson, S. E. (1981). The measurement of experienced burnout. Journal of Occupational Behavior, 2, 99-113.

Maslach, C., ve Leiter, M.P. (1997). The truth about burnout: how organizations cause personal stress and what to do about 1t. San Francisco: Jossey Bass.

Meyer J.P., Allen N.J. ve Smith C.A. (1993). Commitment to organizations and occupations: extension and test of a three-component conceptualization. Journal of Applied Psychology, 78(4), 538-551.

Meyer, J. P., Allen, N. J., \& Smith, C. A. (1993). Commitment to organizations and occupations: Extension and test of a three-component conceptualization. Journal of applied psychology, 78(4), 538.

Mowday R.T., Steers R.M. ve Porter L.W. (1979). The measurement of organizational commitment. Journal of Vocational Behavior, 14, 224-247.

O'Reilly, C.; Chatman, J. (1986). Organizational commitment and psychological attachment: the effects of compliance, identification and internalization on prosocial behaviour. Journal of Applied Psychology, $71(3), 492-499$.

Oğuzberk, M., ve Aydın, A. (2008). Ruh sağlığı çalışanlarında tükenmişlik. Klinik Psikiyatri, 11(4), 167179.

Oktik, N. (2001). Turizm sektöründe çalışan kadınların toplumsal değişime etkileri. Muğla Üniversitesi Sosyal Bilimler Enstitüsü Dergisi, 4, 145-151.

Örücü, E., Kılıç, R. ve Kılıç, T. (2017). Cam tavan sendromu ve kadınların üst düzey yönetici pozisyonuna yükselmelerindeki engeller: Balıkesir İli örneği. Yönetim ve Ekonomi Dergisi 14(2): 117-135.

Özdevecioğlu, M. (2013). Algıllanan örgütsel destek ile örgütsel bağl1lık arasındaki ilişkilerin belirlenmesine yönelik bir araştırma. Dokuz Eylül Üniversitesi İktisadi İdari Bilimler Fakültesi Dergisi, 18(2), 113130. 
Özdevecioğlu, M. ve Çakmak Doruk, N. (2009). Organizasyonlarda iş-aile ve aile iş çatışmalarının çalışanların iş ve yaşam tatminleri üzerindeki etkisi. Erciyes Üniversitesi İktisadi ve İdari Bilimler Fakültesi Dergisi, 33: 69-99.

Özkaya, M. O., Kocakoç, İ. D. ve Karaa, E. (2006). Yöneticilerin örgütsel bağlllıkları ve demografik özellikleri arasındaki ilişkileri incelemeye yönelik bir alan çalışması. Yönetim ve Ekonomi: Celal Bayar Üniversitesi İktisadi ve İdari Bilimler Fakültesi Dergisi, 13(2), 77-96.

Seçilmiş, C. ve Kılıç İ. (2017). Örgütsel Güven, İş-Aile Yaşam Çatışması ve İşten Ayrılma Niyeti İlişkisinin Belirlenmesi: Seyahat Acentelerinde Bir Uygulama, Turizm Akademik Dergisi, 4 (1), 65-79.

Sığrı, Ü. (2007). İş görenlerin örgütsel bağlılıklarının Meyer ve Allen tipolojisiyle analizi: Kamu ve özel sektörde karşılaştırmalı bir araştırma. Anadolu University Journal of Social Sciences, 7(2).

Turgut, T. (2011). Çalışmaya tutkunluk: İş yükü, esnek çalışma saatleri, yönetici desteği ve iş-aile çatışması ile ilişkileri. Atatürk Üniversitesi İktisadi ve İdari Bilimler Dergisi, 25 (3-4) 155-179.

Turunç, Ö. ve Çelik, M. (2010). Algılanan örgütsel desteğin çalışanların iş-aile, aile-iş çatışması, örgütsel özdeşleşme ve işten ayrılma niyetine etkisi: Savunma sektöründe bir araştırma. Atatürk Üniversitesi Sosyal Bilimler Enstitüsü Dergisi, 14 (1), 209-232.

Turunç, Ö. ve Erkuş, A. (2010). İş-aile yaşam çatışmasının iş tatmini ve örgütsel bağlllık üzerine etkileri: iş stresinin arac1lık rolü. Sosyal Ekonomik Araştırmalar Dergisi. 10 (19), 415-440.

Tüzünkan, D. (2019). Turizmde Kadın İstihdâmı. Ahmet Vatan (Ed.), Turizmde Kadın Olmak içinde (s. 6784). İstanbul: Değişim Yayınları.

Wang, M., Liu, S., Zhan, Y., ve Shi, J. (2010). Günlük iş-aile çatışması ve alkol kullanımı: Akran içme normlarının ve sosyal desteğin düzeyler arası 1lımlılık etkilerinin test edilmesi. Uygulamalı psikoloji dergisi, 95 (2), 377.

Wayne, J. H., Musisca, N. ve Fleeson, W. (2004). Considering the role of personality in the work-family experience: Relationships of the big five to work-family conflict and facilitation. Journal of Vocational Behavior, 64 (1), 108-230.

Yurtseven, Ö. (2008). İş-aile çatış̧ması, iş tatmini ve işten ayrılma niyeti ilişkisi turizm işletmesinde bir uygulama. Akdeniz Üniversitesi Sosyal Bilimler Enstitüsü, Yayımlanmamış Yüksek Lisans Tezi, Antalya.

Yüceler, A. (2009). Örgütsel bağlllık ve örgüt iklimi ilişkisi: Teorik ve uygulamalı bir çalışma. Selçuk Üniversitesi Sosyal Bilimler Enstitüsü Dergisi, (22), 445-458.

Yüksel, İ. (2005). İş-aile çatışmasının kariyer tatmini, iş tatmini ve iş davranışları ile ilişkisi. İktisadi ve İdari Bilimler Dergisi, 19(2), 301-314. 